\title{
Dominação e contrapoder o candomblé no fogo cruzado entre construções e desconstruções de diferença e significado
}

\section{Diferenciando algumas noções de alteridade e de resistência}

Periodicamente, geralmente aos fins de semana, pessoas se reúnem em todos os cantos do Brasil em templos, também chamados de terreiros, nos quais promovem longas cerimônias que têm como objetivo religioso principal a invocação de orixás. Muitos outros brasileiros e brasileiras, que têm receio de se aproximar de tais cerimônias, não deixam de procurar, em determinados momentos de sua vida, os líderes de tais comunidades para consultar o oráculo dos búzios. Se a maioria dos brasileiros conhece algumas características básicas dos orixás e até partes da mitologia que os envolve e constitui, são poucos, no entanto, aqueles que se declaram abertamente praticantes de uma religiosidade específica relacionada com tais divindades. Há uma grande diversidade de práticas ritualísticas e de crenças que envolvem a veneração dos orixás que os adeptos costumam identificar a "divindades africanas" e, por vezes, também associam ou até "equiparam" a santos católicos. De qualquer forma, a maioria dos adeptos entende que, pelo menos, algumas partes centrais de sua religiosidade estão vinculadas a uma "tradição" ("proveniência") que diverge daquele poderoso referencial religioso que durante séculos foi absolutamente hegemônico no Brasil.

O candomblé constitui uma sobrevivência cultural e deve ser visto como uma forma de resistência negra. Tal avaliação, frequente nos anos 1980, não 
reflete somente uma determinada perspectiva militante ${ }^{1}$, mas condiz também com modelos explicativos antropológicos muito comuns à época. Não que essa afirmação esteja necessariamente errada: o que se verificou como sendo problemático, a partir de novas perspectivas teóricas desenvolvidas no âmbito da antropologia e dos chamados estudos culturais e pós-coloniais, é a maneira simplista pela qual durante muito tempo noções como dominação e resistência e - diretamente relacionada a estes dois conceitos -, sobretudo, a questão da diferença foram abordadas.

Nos primeiros estudos antropológicos, que buscavam tratar de temas relacionados com a população negra no Brasil, vigorava a busca por raízes e origens. Tal preocupação pode ser verificada tanto naquelas análises pioneiras de Nina Rodrigues, na virada do século XIX para o século XX, que seguia parâmetros raciais-biológicos mesclados com orientações evolucionistas, quanto nos trabalhos de uma primeira geração de estudiosos que procuravam diferenciar entre herança biológica (raça) e mundo da simbolização (cultura) e, seguindo os ensinamentos de Franz Boas, começavam a operar com uma noção sistêmica de cultura, isto é, com a ideia de uma pluralidade cultural. Assim, um pesquisador como Arthur Ramos, que na década de 1940 contribuiu, de forma decisiva, para a teorização sobre a noção de aculturação, dedicava-se ao estudo dos "padrões de culturas que os negros transportaram da África para o Novo Mundo" (RAMOS, 1979 [1935], p. XXII) e, especialmente, de sua religiosidade, inclusive com o objetivo de melhor avaliar possíveis processos de adaptação e transformação.

Já nas avaliações de Roger Bastide, o candomblé transformar-se-ia num exemplo emblemático de "resistência cultural". Para este estudioso, o candomblé constituía "um verdadeiro pedaço da África transplantada", um mundo que "une esses homens, mulheres e crianças num todo coerente e funcional", no qual se expressava "o triunfo das normas coletivas" (BASTIDE, 1985 [1960], p. 312, 313, 522). Apoiando-se, inclusive, em inovações conceituais como "enquistamento cultural" e "princípio de corte", Bastide argumentaria que o candomblé resiste a qualquer forma de mistura e às transformações

Cf. p. ex. o uso do termo "sobrevivências religiosas" no texto que convocava para o I Congresso Negro Brasileiro, subscrito por Guerreiro Ramos, Edison Carneiro e Abdias do Nascimento em maio de 1949 (MOURA, 1983, p. 153-155), ou ainda as avaliações de Maria de Lourdes Siqueira, publicadas no Jornal Nacional do Movimento Negro Unificado, em 1989 (n. 16), a respeito da força de resistência do candomblé que, segundo essa intelectual e militante, "guarda e mantém o núcleo de identidade do negro na Bahia" (Jornal Nacional do Movimento Negro Unificado, 1989, n. 16, p. 9). 
provocadas pela modernização ${ }^{2}$. O cientista francês diferenciava dois tipos de "resistência negra" no Brasil - a cultural e a política ${ }^{3}$-, que ele via como antagônicas e, de certa forma, excludentes (BASTIDE, 1985, p. 74).

Bastide opunha explicitamente o mundo da política ("movimentos de protesto racial") ao mundo da religião, que o autor tendia a tratar como uma espécie de protótipo de cultura (ou "subsistema cultural"). "Em política", escreve Bastide, "há um certo esquema de atividades, luta dos partidos pelo poder, liderança e organização de grupos de interesse"; e qualquer mudança de valores e atitudes repercutirá numa reformulação das instituições políticas ${ }^{4}$. Já o campo da cultura (religião) era concebido por Bastide como um mundo muito mais coeso e estático. "Na religião", avalia o autor, "ao contrário,

2 Bem diferente foi a avaliação da macumba (umbanda). Enquanto Bastide relacionava o candomblé com o pensamento religioso que seguiria a lei do simbolismo e das analogias, via na "macumba" a manifestação do "pensamento mágico", que, segundo ele, seria dominado pela lei da acumulação, da intensificação e da adição. É essa atitude, ligada ao desejo individual, à paixão obstinada e à ilogicidade vibrante, que possibilitaria as misturas culturais, isto é, a manifestação do sincretismo (BASTIDE, 1985, p. 382-384). Se Bastide descreve o candomblé como uma religião que resiste à modernidade, associa, por outro lado, o surgimento da umbanda a processos de industrialização e urbanização, concebidos como fatores responsáveis pela proletarização do negro, bem como pelo processo de desagregação social e de assimilação cultural. Percebe-se que, nesta análise, o candomblé permanece sob o prisma da cultura, enquanto a umbanda é interpretada como parte integrante da sociedade moderna (não mais como formas de "resistência cultural"); ambos sofrem, inclusive, julgamentos morais baseados em parâmetros valorativos da sociedade burguesa ocidental:"O candomblé era e permanece um meio de controle social, um instrumento de solidariedade e de comunhão; a macumba resulta no parasitismo social, na exploração desavergonhada da credulidade das classes baixas ou no afrouxamento das tendências imorais, desde o estupro até, frequentemente, o assassinato" (BASTIDE, 1985, p. 414). Para um aprofundamento das noções de enquistamento cultural, princípio de corte e sincretismo usadas por Bastide, cf. Capone (2008, p. 255-292).

3 A tendência de conceber o espaço da cultura como um "espaço politicamente neutro" pode ser encontrada em vários outros antropólogos, inclusive ainda em épocas não tão remotas. João Baptista Borges Pereira, por exemplo, distingue num artigo publicado em 1984 entre "resistência de cultura"e "cultura de resistência". O autor, pioneiro no tratamento do tema "o negro e a mídia no Brasil", entende o processo de "resistência cultural" de forma semelhante a Bastide, como uma resistência que um "corpo orgânico" exerce contra pressões ou obstáculos e cujo conteúdo político é algo indefinível: "Todo esse processo de resistência cultural se dá difusamente, não obedecendo a lideranças formais nem a propostas explicitadas de resistência - a não ser o da resistência enquanto tal -, o que impede o analista de o colocar dentro de um referencial mais sistemático, como ocorre com relação a projetos políticos de resistência étnica do grupo" (PEREIRA, 1984, p. 182 - grifos nossos). Pereira explica que a cultura que resiste pode ser transformada em "cultura de resistência". Mas, para ocorrer isso, essa mesma cultura precisa, segundo o autor, ser "manipulada" intencionalmente por determinado grupo defensor de um projeto político claro que visa à busca de uma identidade étnica. Assim, Pereira acaba criando, mais uma vez, uma dicotomia típico-ideal entre um mundo ambíguo ou neutro dos símbolos culturais (i.é., sem conteúdo político específico) e um mundo racional, lógico e formal da disputa política.

4 O próprio Bastide estudou e comentou o surgimento e as transformações de uma das expressões de "resistência política do negro", a Imprensa Negra de São Paulo dos anos 1920 e 1930 (BASTIDE, 1983, p. 129-156). 
o passado resiste à mudança, pois a tradição é sagrada em essência. O novo deve, portanto, se inserir no velho, sem destruí-lo." (BASTIDE, 1985, p. 468).

A noção "resistência cultural", que nas análises de Bastide ganha a conotação de uma resistência quase "física" de um "corpo orgânico", condiz com uma tendência hegemônica nos estudos antropológicos daquele período que, ao privilegiar a análise de funções e/ou estruturas e/ou padrões de sistemas culturais, tendia a não abordar temas como poder, conflito, discriminação e desigualdade inerentes aos contextos culturais pesquisados.

Essa noção sistêmica e sincrônica das culturas, como entidades coesas e homogêneas, que marcava, no fundo, as três grandes teorias antropológicas desenvolvidas a partir do início do século XX (culturalismo norte-americano, funcionalismo e estruturalismo) ganharia mais dinâmica a partir das décadas de 1970 e 1980, quando pesquisadores como Pierre Bourdieu (1972) e Marshall Sahlins (1981), começaram a direcionar seus estudos para usos particulares e estratégicos dos repertórios socioculturais, em virtude de interesses pessoais e grupais. Interessava agora entender não somente como o sistema molda a prática, mas sobretudo também como o próprio sistema é moldado pela ação dos agentes sociais: isto é, como a prática contribui para reproduzir o sistema/estrutura e como o sistema/estrutura pode ser transformado/a e/ou mantido/a pela prática. Foram preocupações teóricas como estas que introduziram e deram destaque à noção de "agenciamento" (agency) em estudos antropológicos. Baseando-se em tais perspectivas teóricas, Sahlins vem criticando a visão segundo a qual o avanço do capitalismo modernizador engolirá necessariamente as diferentes culturas no mundo. Em vários trabalhos, Sahlins tem procurado mostrar que a relação com o mundo capitalista não leva necessariamente a uma "deculturação", senão que, pelo contrário, pode até levar à "intensificação cultural" na medida em que os agentes locais buscam e conseguem incorporar objetos e ideias estrangeiros (que vêm de fora) ao seu sistema cultural estabelecido e atribuir-lhes os seus significados locais (SAHLINS, 1997).

A introdução dos termos identidade e etnicidade no repertório analítico antropológico abriu novas perspectivas e conferiu novo dinamismo às análises das diferenças. Fredrik Barth mostrou, já em 1969, que a relação entre cultura e identidade étnica não é obrigatoriamente uma relação simples de "um para um" (BARTH, 1969, p. 14). O que determina a definição e redefinição da(s) fronteira(s), diz Barth, não é necessariamente a diferença cultural 
"real observável", e sim muito mais as "relações" que existem entre as pessoas (os grupos) e, acima de tudo, a maneira como as diferenças são percebidas pelos agentes sociais. A razão da "identificação" (e da diferenciação) não estaria, portanto, tanto em diferenças que existem "objetivamente", mas em diferenças que são concebidas pelos próprios agentes como socialmente relevantes ${ }^{5}$. Com essas reflexões, Barth propõe um deslocamento do foco de análise: da constituição interna (valores, costumes) das culturas para as fronteiras étnicas ou, mais especificamente, para a criação e a manutenção das fronteiras do grupo. Mesmo que não haja, evidentemente, um consenso entre os antropólogos no que diz respeito ao uso e ao conteúdo do conceito de identidade étnica, pode-se afirmar que as contribuições de Barth e de outros "antropólogos teóricos da identidade" abriram espaço na análise para o olhar dos próprios pesquisados sobre aquilo que os diferencia dos "outros".

A chamada antropologia interpretativa, que aborda culturas como textos interpretáveis concebidos, a princípio, como não conclusivos (GEERTZ, 1973), abriria caminho para uma autocrítica da produção antropológica, denominada pela literatura especializada de virada literária, dialógica e reflexiva, que se expressaria, de forma mais cristalina, na chamada perspectiva pós-moderna. Deixando de acreditar que a pesquisa antropológica poderá chegar a um plano intersubjetivo em torno dos significados dos signos, tal como Geertz supunha, antropólogos pós-modernos buscam estratégias analíticas que permitam expressar as múltiplas vozes, ou seja, a polifonia que, de acordo com estes autores, cria e recria a vida em sociedade. Tal orientação teórica romperia definitivamente com explicações sistêmicas da realidade e passaria assim a se concentrar na relação dialógica entre pesquisador e pesquisado, tida como responsável pela produção de conhecimento.

O desvio de enfoque de análise, propagado por James Clifford, das raízes (roots) para as "rotas"/itinerários (routes) percorridos e vivenciados pelos sujeitos tornou-se também perceptível no trabalho de vários antropólogos que pesquisam as religiões de matriz africana no contexto do Atlântico Negro (MATORY, 2005; PALMIÉ, 2008). No seu impactante livro, Black Atlantic

Com o uso do conceito "emblema de diferença", Barth busca avaliar como em determinados contextos e em virtude de interesses particulares as pessoas (indivíduos e grupos) selecionam do seu repertório cultural (vestimenta, língua, moradia etc.) algum signo ("traço diacrítico") para delimitar-se de outros e para exibir uma identidade comum.

6 Para uma análise mais completa sobre a noção de identidade/etnicidade, cf. p. ex. Poutignat e StreiffFenart (1997), Malešević (2004) e Hofbauer (2009). 
religion (2005), Matory combate a busca de raízes culturais, afirmando que aquilo que é chamado recorrentemente de "memória", "sobrevivência" ou "tradição cultural" nos dois lados do Atlântico "é, na verdade, sempre uma função de poder, negociação e re-criação estratégica” (MATORY, 2005, p. 70).

A ênfase num viés analítico discursivo (Foucault) levou diferentes antropólogos a criticar fortemente o essencialismo, o holismo e a homogeneidade presentes na noção clássica de cultura (ABU-LUGHOD, 19917). Tal crítica afasta implicitamente a possibilidade de se pensar a cultura como algo (sistema, estrutura) que orienta a percepção e a ação dos sujeitos e, concomitantemente, já não admite pensar a "resistência cultural" como uma resistência quase física que ocorre independentemente das intencionalidades subjetivas. Uma abordagem pós-moderna radical, que foca o olhar analítico na articulação de projetos individuais, já não possui meios analíticos para avaliar o tema das relações de dominação nem o das estratégias de resistência, que se tornam, consequentemente, questões inócuas.

Se até relativamente pouco tempo atrás as variações culturais eram vistas pelos pesquisadores como um "valor em si", merecendo, inclusive, ser fortalecidas diante das imposições do mundo moderno, percebe-se que, nas últimas décadas - devido ao acirramento de processos referentes à globalização, assim como às reflexões sobre identidade e às críticas pós-modernas, pós-estruturalistas e pós-coloniais -, ideias fundantes como "autenticidade" e "tradição" começaram a ser revistas ${ }^{8}$. Eriksen (2001, p. 3) lembra que os críticos do holismo cultural não apenas apontaram para o fato de que existem grandes variações internas dentro de cada cultura, mas mostraram também que "ideologias tradicionalistas", que enfatizam as "raízes" e a "pureza cultural", surgem com frequência no contexto de processos de modernização e globalização.

\footnotetext{
Ao considerar a noção de cultura "uma ferramenta essencial para a fabricação de alteridades", AbuLughod (1991) propõe substituí-la por termos como "prática" ou "discurso" que, diferentemente de "cultura", não sugeririam "homogeneidade" nem "holismos". Evidentemente, tal postura provocou contrarreações da parte de outros antropólogos, tal como a de Sahlins. Este antropólogo tem criticado, com certo sarcasmo, que a postura pós-moderna "radical" trata o poder como uma espécie de "buraco negro", no qual deposita tudo aquilo que tem sido objeto valoroso para a antropologia até recentemente (diferentes formas de viver, de organização social e de pensamento, valores, éticas, ontologias, formas religiosas, etc.) (SAHLINS, 2002, p. 20).

8 Nos estudos sobre o candomblé, a publicação do livro Vovó nagô e papai branco (1988), de Beatriz Góis Dantas, constituiu certamente um marco. Ao enfatizar a colaboração ativa de intelectuais (antropólogos) na construção e na recriação da tradição, esse trabalho contribuiu para desviar o foco de atenção da busca das raízes culturais e de uma suposta essência africana na religião do candomblé.
} 
$\mathrm{Na}$ medida em que cada vez mais antropólogos se convenceram de que o foco de análise não deveria ser as diferentes culturas "em si", mas a maneira como os agentes sociais fazem uso dos símbolos culturais em situações específicas, analisar a "cultura como ela é", sem levar em consideração o dinamismo que envolve o "agenciamento", torna-se cada vez mais uma prática antropológica ultrapassada que - assim soa a acusação - contribui para promover uma ideia essencializada da cultura.

Partindo de um ponto diverso do das pesquisas antropológicas, os estudos pós-coloniais têm dado contribuições importantes para a compreensão de processos de dominação e de articulação de contrapoderes. A crítica póscolonial dirige-se, em primeiro lugar, às teorias da modernização concebidas como fundantes da maior parte das abordagens clássicas em sociologia. Nestas grandes narrativas hegemônicas (tanto de viés liberal quanto marxista), desenvolvidas nos centros acadêmicos ocidentais, a modernidade vem sendo tratada como um fenômeno diretamente vinculado ao mundo ocidental. Tais discursos pregam, entre outras coisas, que a modernização teria começado na Europa com a Revolução Industrial e, de lá, ter-se-ia espalhado para todo o globo (KNÖBL apud COSTA, 2005, p. 244). Ao assumir uma postura historicista e ao defender implícita ou até explicitamente a ideia de que existe somente um caminho possível para realizar o projeto da modernidade (sendo a história do Ocidente o modelo e o melhor exemplo), as teorias clássicas da modernização criam um hiato quase insuperável entre o Ocidente e o resto do mundo ("the West and the rest", nas palavras de Stuart Hall).

Os críticos pós-coloniais querem, ao contrário, mostrar que o que vem sendo chamado de modernidade foi construído com a participação ativa de populações que, em muitos clássicos, costumam ser tipificadas como "prémodernas" e/ou "subdesenvolvidas". Assim, Stuart Hall chama a atenção para o fato de que o discurso hegemônico da modernização, que remonta ao período colonial, tem reduzido a história moderna a uma ocidentalização paulatina e heroica do mundo, omitindo que, por meio da expansão colonial, diferentes historicidades e temporalidades foram violentamente fundidas e mescladas (HALL, 1996a, p. 252).

Autores como Randeria (1999) e Pieterse (2010) têm criticado o universalismo reivindicado pela modernidade ocidental, desmascarada agora como uma história particular, que faria com que os não-ocidentais fossem colocados na "sala de espera da história" (CHAKRABARTY, 2000, p. 8). Assim, 
Randeria enfatiza as múltiplas imbricações que caracterizam a modernidade (entangled modernity). Ela chama especial atenção para as diversas e paralelas histórias que são compartilhadas, se cruzam e se mesclam sem que sejam representadas como tal, e destaca as interdependências entre muitas dessas histórias modernas sem esquecer de incluir, na sua análise, as assimetrias nas relações de $\operatorname{poder}^{9}$ (COSTA, 2005, p. 229).

A desconstrução dos diversos binarismos localizados nas narrativas hegemônicas (West-rest; moderno-tradicional; colonizadores-colonizados, secularizado-religioso; sociedades com história-sociedades sem história), que teriam não somente guiado a produção de conhecimento, mas também justificado intervenções políticas que incluíam, com frequência, o uso da violência, torna-se, portanto, um dos objetivos mais importantes do projeto pós-colonial. Trabalhos pós-coloniais mais recentes têm investido, inclusive, na construção de soluções teóricas que venham a servir de base a lutas contra-hegemônicas distintas de uma mera inversão da valorização do par conceitual "o Ocidente e o resto". Compreende-se agora que a luta anticolonial "clássica" ocorreu ainda dentro da episteme colonial, por meio da fixação da suposta diferença entre colonizador e colonizado, na forma de movimentos nativistas e nacionalistas ${ }^{10}$. Os pós-coloniais exigem, portanto, uma outra atitude. O objetivo declarado é a desconstrução de todo tipo de essencialismo na concepção das diferenças humanas: almeja-se a diluição crítica de todas aquelas fronteiras vistas como legado do colonialismo, por um lado, e das lutas anticoloniais, por outro (COSTA, 2006, p. 89). Dessa forma, i.é., descolonizando a própria maneira de pensar, o projeto pós-colonial procura "reinscrever" o colonizado na modernidade: não mais como "o outro" do Ocidente, mas sim como parte integrante e constitutiva daquilo que foi construído - discursivamente - como moderno.

9 É neste ponto, aliás, que vários autores pós-coloniais fazem questão de se diferenciar de análises marcadamente pós-modernas. Acusam-nas de não levar em consideração as relações de poder estabelecidas e de reduzir a articulação da(s) diferença(s) a um exercício da liberdade liberal de identificação. Segundo a visão pós-colonial, qualquer fenômeno social existe somente em relação a uma estrutura de poder e saber, e é moldado por ela. Dessa forma, entende-se que até posicionamentos de crítica e de resistência encontram-se imbricados com posicionamentos hegemônicos contra os quais se dirigem (REUTER e VILLA, 2010, p. 17).

${ }^{10}$ A maioria dos pós-coloniais atuais já não se contenta com as "estratégias de inversão" elaboradas pelos movimentos anticolonialistas e antirracistas históricos, como, por exemplo, o Pan-africanismo e a Négritude. Tais estratégias teriam buscado atribuir conotações positivas àqueles conceitos (p. ex., à categoria "negro") que teriam posto os não-ocidentais não apenas em oposição, mas também numa posição subalterna em relação ao "mundo ocidental civilizado" (cf. p. ex. as reflexões de HALL, 2003, p. 347; e GILROY, 2000, p. 37-43). 
A incorporação de premissas teóricas fundamentais de Foucault a respeito da relação entre discurso, saber e poder ${ }^{11}$ conferiu à perspectiva pós-colonial um poderoso instrumental analítico, que lhe permitiu elaborar críticas viscerais às formas de representação que o Ocidente moderno desenvolveu. Baseandose em tais premissas, os pós-coloniais têm também sustentado que as ideias discriminatórias sobre os chamados selvagens e primitivos foram fulcrais para fundamentar a emergência da noção iluminista de um sujeito autônomo que se entende como autodeterminado e superior em relação aos "seres não civilizados" (VARELA, 2005, p. 16). Para Hall, a noção clássica do sujeito cartesiano iluminista constitui, acima de tudo, um ideário construído no momento da expansão colonial, uma "autorrepresentação", que visaria afirmar um self europeu em oposição aos colonizados em ultramar. Ao "outro" caberia, nesse projeto discursivo, o retrato inverso (o "lado negro") do ideal iluminista e da ansiada modernidade (HALL, 1996b, p. 221). De acordo com autores como Hall, a ideia da "identidade completa", presente tanto no sujeito cartesiano quanto no sujeito sociológico "clássico", nunca se realizou de fato - nem mesmo no mundo ocidental - e revela-se, hoje, produto de uma fantasia ocidental que não se sustenta mais diante da enorme variedade de identidades possíveis (HALL, 2001, p. 7). A partir de reflexões como essas, a questão das diferenças seria repensada não somente no plano individual, mas também no coletivo.

$\mathrm{Na}$ análise pós-colonial, que incorporará os ensinamentos de Derrida a respeito da articulação dos signos, a diferença já não é tratada como uma fronteira entre dentro e fora: transforma-se num locus dentro do "próprio centro" (HEIN, 2006, p. 41-42). A transposição das fronteiras para o interior das culturas transforma a cultura num lugar incerto de significação. Já os estudos culturais, ao partirem de preocupações diferentes daquelas da antropologia clássica, ${ }^{12}$ tendiam a abordar a cultura, em primeiro lugar, como

\footnotetext{
${ }^{11}$ Ao recorrer às diretrizes básicas da análise de discurso de Foucault, Edward Said publicou, em 1978, o livro Orientalismo, tido como texto fundacional do pós-colonialismo. Além das ideias de Foucault, evidentemente vários outros autores e conceitos - como p. ex. a noção de "hegemonia" (Gramsci), o conceito marxista de "subalternidade", a "metáfora do espelho" (Lacan), assim como a ideia da "desconstrução" (Derrida) - inspiraram os diferentes autores pós-modernos. Para um aprofundamento da questão, cf. p. ex. Loomba (2005) e Varela (2005).

12 Ainda que os estudos culturais tenham nascido antes dos estudos pós-coloniais (consolidando-se na década de 1970 em torno do Centre for Contemporary Cultural Studies, em Birmingham, cujo diretor mais atuante foi Stuart Hall), pode-se afirmar que existem muitas sobreposições e mesclas entre ambas as áreas tanto em termos temáticos quanto teóricos, de maneira que se torna difícil considerá-las hoje dois campos acadêmicos distintos. Sobre o desenvolvimento dos estudos culturais, cf. p. ex. Marchart (2008).
} 
um campo no qual disputas por poder, conflitos em torno de significados e processos de identificação e diferenciação são articulados e negociados. $\mathrm{Ou}$ seja, ao invés de destacar a força integrativa e homogeneizadora das culturas, os estudos culturais e pós-coloniais têm procurado chamar a atenção para a ausência de consensos em questões relacionadas a valores e significados nas sociedades atuais. Com a introdução do neologismo "différance", que afirma, entre outras coisas, que (1) nenhum contexto discursivo particular esgota plenamente o repertório de significações atribuíveis a um signo, e que (2) significantes e significados nunca se correspondem inteiramente, Derrida criou as bases teóricas que tornaram possível romper definitivamente com a ideia da diferença preexistente ("diferença ontológica") ${ }^{13}$. A instabilidade inerente à produção de significado, descrita pelo termo "différance", servirá aos pós-coloniais também como argumento em prol da noção de que a "prisão simbólica" imposta pelos discursos hegemônicos discriminatórios e estereotipados pode ser rompida e que, portanto, as lutas contra-hegemônicas fazem sentido.

Partindo das premissas de Foucault e Derrida, Homi Bhabha argumenta que o discurso colonial nunca foi tão uniforme como ele próprio se apresentava e, portanto, não foi capaz de operar sem contestação, distúrbios e irrupções. As identidades por meio das quais o colonialismo pretendeu fixar "senhores" e "subjugados" revelaram-se surpreendentemente instáveis e frágeis, afirma Bhabha. Tal argumento lhe permite questionar a própria existência de uma oposição binária clara entre colonizadores e colonizados.

Homi Bhabha, um dos autores pós-coloniais que mais tem explorado o modelo linguístico-discursivo de análise, entende que a tentativa de fixar significados não poderia ser alcançada plenamente, uma vez que no processo de "tradução" de ideias particulares e de teorias produzidas na metrópole surgiriam inevitavelmente hibridações. Ou seja, o contexto colonial não permitiria uma repetição do original sem modificações, já que o processo de tradução - a repetição num outro contexto - abre inevitavelmente brechas e fissuras no "texto" original.

Ao operar com conceitos como hibridação, "mímica", e "terceiro espaço", Bhabha procura não apenas reavaliar o tema da resistência, mas também elaborar um novo quadro conceitual para tematizar a questão da diferença

3 Para um aprofundamento das ideias de Derrida, cf. Kimmerle (2000). 
em $\operatorname{si}^{14}$. Assim, a noção de mímica, concebida como uma "repetição com diferença", ajuda-o a defender a ideia de que a imitação no contexto colonial não deve ser meramente vista como um ato de submissão incondicional ao colonizador. Pelo contrário: os deslizamentos, excessos e diferenças que emergem do processo de imitação fariam com que a mímica se tornasse ao mesmo tempo semelhança e ameaça, conferindo-lhe um potencial subversivo, qual seja, o de minar as grandes narrativas do colonialismo (BHABHA, 2001, p. 130-131).

Seguindo este raciocínio, Bhabha refere-se à hibridação não como uma junção de dois elementos que dão vida a um terceiro, mas muito mais como aquilo que ele denomina "terceiro espaço": um momento que torna possível novos posicionamentos dos sujeitos, em que os signos são deslocados de seu referencial hegemônico e ainda não foram inscritos num outro sistema de representação totalizante (BHABHA, 2001, p. 67-68). É esse deslocamento, para Bhabha, que caracteriza o momento da hibridação do signo e o possível momento da resistência: ele diz respeito à articulação da ambiguidade que retira de todas as classificações padronizadoras sua completude e inequivocidade (COSTA, 2005, p. 240) ${ }^{15}$.

Outros pensadores pós-coloniais, como Gilroy e Hall, não põem em xeque a importância da construção discursiva de significados, mas, ao delimitaremse de uma postura pós-estruturalista extrema, questionam a ideia de que esta seja a única fonte de poder. Para Hall, a questão do poder e do político não se reduz ao problema da língua e da representação. Esse cientista entende que tanto o textualismo quanto o economicismo não dão respostas satisfatórias para a questão do local do poder, ao mesmo tempo em que não põe em dúvida a existência de algo como um poder econômico e político anterior à sua articulação verbal (linguística) (apud MÜLLER-FUNK, 2006, p. 284).

\footnotetext{
14 Logo no início do seu clássico, O local da cultura, Bhabha polemiza contra a ideia de avaliar a"representação da diferença (...) como o reflexo de traços culturais ou étnicos preestabelecidos [pre-given], inscritos na lápide fixa da tradição", também porque entende que "os termos de embate [engagement] cultural, seja através de antagonismo ou afiliação, são produzidos performativamente" (BHABHA, 2001, p. 20).

15 Para Bhabha (2001), o momento da hibridação é fortuito, aleatório; é uma interação contingente que independe da vontade dos sujeitos. Ou seja: de acordo com essas ideias, o ato subversivo não pode ser controlado, em última instância, pelos sujeitos. Dessa forma, a concepção teórica de Bhabha não abre espaço para abordar aquilo que outros autores chamam de agency. Costa avalia que é impossível extrair das ideias de Bhabha uma teoria ou estratégia de resistência e/ou de transformação social, como diversos movimentos sociais vêm fazendo (COSTA, 2006, p. 94; 101-102).
} 
No entanto, em suas reflexões sobre a noção de identidade e etnicidade, as orientações fundamentais da análise de discurso tornam-se, outra vez, nítidas: Hall argumenta que são os discursos que produzem um lugar para o sujeito, que abrem um espaço para um posicionamento. No fundo, indivíduos e coletividades só podem se articular por meio de discursos. "Articulação" é o conceito-chave usado por Hall para descrever esse posicionamento e reposicionamento constante dos sujeitos.

De acordo com Hall, a "identificação opera por meio da différance" e envolve, assim, a "marcação de fronteiras simbólicas"; ao mesmo tempo, esse processo provocaria sempre "uma sobredeterminação ou uma falta, mas nunca um ajuste completo, uma totalidade" (HALL, 2000, p. 106). As identidades emergiriam, portanto, "no interior do jogo de modalidades específicas do poder", e poderiam ser entendidas como "pontos de apego temporário às posições-de-sujeito que as práticas discursivas constroem para nós” (HALL, 2000, p. 109; 112). Assim, Hall entende que identidades individuais e coletivas articulam-se como um processo constante de negociação, como uma luta por significados dentro de discursos poderosos. Com a introdução do termo "novas etnicidades", Hall (1991) posicionou-se também contra as velhas concepções essencializadas de grupo étnico e procurou justamente enfatizar a dimensão discursiva na construção das identidades coletivas.

Se, por um lado, podemos perceber que há, certamente, pontos de contato na maneira como os cânones antropológicos e pós-coloniais lidam com a noção da diferença, também há, por outro lado, diferenças. Ambas as "tradições" produziram críticas aos essencialismos e têm chamado a atenção para o fato de que os processos de identificação são permeados por interesses, disputas de poder, conflitos. No entanto, pode-se argumentar que os pós-coloniais aproximam-se da questão da diferença "de fora para dentro", centrando sua análise e crítica em narrativas hegemônicas sobre os não-ocidentais, os nãomodernos etc., ao passo que a antropologia, por sua vez, tende a inverter a direção do percurso analítico: busca uma compreensão da diferença que parte "de dentro" para, a partir daí, olhar "para fora".

O "lado forte" da antropologia tem sido o de avaliar, a partir de sólidas pesquisas de campo, diferentes formas de organização social, bem como diferentes sistemas de valores, éticas e ontologias. Esse olhar relativizante, ao mesmo tempo em que abriu as portas para compreender por dentro "outras 
culturas", fez com que não poucas monografias clássicas tendessem a evitar abordar questões como conflito, poder, discriminação e desigualdade. Já a perspectiva de cultura defendida pelos estudos culturais e pós-coloniais, vista como um espaço dentro do qual as relações de poder são negociadas, desvia o foco de análise de possíveis funções, padrões ou estruturas culturais e tende a negar à cultura o papel de fonte de percepção e atuação humanas.

A antropóloga norte-americana Sherry Ortner localiza nos estudos que seguem a orientação pós-colonial um certo paradoxo. De um lado, pretendem abrir espaço para a articulação de formas de resistência contra as grandes narrativas e projetos hegemônicos; de outro, são poucos os que se dispõem a conhecer de perto e a falar sobre os mundos daqueles que resistem. De acordo com essa crítica, a atitude dos pós-coloniais desestimularia a prática etnográfica e enfraqueceria as culturas, tornando-as ralas (thinning culture). Tanto a perspectiva pós-moderna quanto a pós-colonial "mais radical" transformariam, em última instância, "o outro" num "efeito do(s) discurso(s)" (ORTNER, 2006, p. 42-62) ${ }^{16}$.

Resumindo tal comparação entre cânones, pode-se afirmar que os estudos antropológicos chamam a nossa atenção, em primeiro lugar, para os diferentes significados que são produzidos pelos diversos grupos humanos nos variados contextos culturais, enquanto as pesquisas pós-coloniais nos alertam, entre outras coisas, tanto para o impacto que os discursos hegemônicos têm sobre as formas de representação quanto para a instabilidade e provisoriedade na produção dos significados em $\mathrm{si}^{17}$.

Tendo como pontos de referência teórica ensinamentos antropológicos e pós-coloniais, sobretudo os que dizem respeito à compreensão da prática sociocultural e da construção e desconstrução das diferenças, apresento, a seguir, um pequeno esboço histórico do candomblé, no qual serão destacadas disputas em torno da definição de identidades e significados. É, antes, uma colcha de retalhos, sem nenhuma pretensão de completude.

\footnotetext{
${ }^{16}$ Para Ortner, a dissolução do sujeito em "efeitos subjetivos" não pode ser a única resposta à noção do sujeito reificado. Ao invés de desconstruir os sujeitos, dever-se-ia mostrar como os agentes sociais são social e culturalmente construídos e como "cada cultura, cada subcultura e cada momento histórico constrói sua própria forma de agenciamento (agency), seus próprios modos de implementar o processo de refletir sobre o self e o mundo (...). Agency não é uma entidade que exista à parte da construção cultural (...)" (ORTNER, 2006, p. 57).

17 Para um aprofundamento desta comparação, cf. Hofbauer (2009).
} 


\section{Catolicismos africanizados, religiosidades de matriz africana ou fusões inovadoras? Focando disputas em torno das diferenças e das identidades}

Uma série de leis, como as Ordenações Manuelinas (1514) e Filipinas (1603), que obrigavam os senhores a batizar os seus escravos dentro de um prazo estabelecido (três e seis meses, respectivamente), revela que, desde o início da colonização, a Coroa portuguesa levava a sério o projeto da catequese. Na "era dos descobrimentos", o projeto da conversão andava par a par com o da colonização: as missões tornavam-se um instrumento de pacificação e de dominação ${ }^{18}$. Vários estudiosos, porém, chamam a atenção para a crônica falta de padres e para a dificuldade de promover a catequese em fazendas e plantações que se encontravam espalhadas pelo interior. Devido a essa precariedade da catequese, ter-se-ia disseminado entre a população local um catolicismo popular, de caráter medieval, em cujo centro se encontrava a veneração de santos católicos mesclada com certas crenças ibéricas não-cristãs ${ }^{19}$.

Não há dúvida de que a origem do fenômeno sociocultural do candomblé está diretamente ligada às complexas relações, bem como à convivência conflituosa, dos escravos e de seus descendentes com o mundo dos senhores e, particularmente, com o catolicismo. A história do candomblé é profundamente marcada por processos ligados à exploração escrava e à discriminação racial que, de certa maneira, impunham o quadro de condições e relações sociais dentro do qual o jogo dos posicionamentos se desenrolou. As disputas em torno do incluir e do excluir, sobretudo em torno daquilo que adeptos e não-adeptos entendem como negro e branco (como raça, cultura, religião e/ ou identidade negra e branca - ou, ainda, como "misturado"/ "sincrético"), podem ser vistas como parte intrínseca da formação e da transformação do fenômeno do candomblé. É sabido que uma reinterpretação daquele trecho em que aparece pela primeira vez a palavra "escravo" no Velho Testamento

\footnotetext{
${ }^{18}$ No caso do Brasil, a Companhia de Jesus, fundada no espírito da Contrarreforma, assumiu o papel de uma espécie de "supervisor ideológico" do projeto colonial até as reformas pombalinas: as pregações e os escritos de vários religiosos importantes ligados a esta ordem (p. ex. A. Vieira, Antonil, Benci) tiveram uma importância fundamental na justificação do tráfico negreiro e do uso de mão de obra escrava negra no Brasil.

${ }_{19}$ Os capelães, que passavam eventualmente nas fazendas, teriam antes atuado como uma espécie de preboste dos senhores, que pouco interesse mostravam numa formação ortodoxa dos escravos.
} 
(Gênesis, cap. IX), que relacionava culpa, imoralidade e também a cor negra ao fenômeno da escravidão - e que seria usada, durante muito tempo, como discurso justificatório hegemônico da escravização de "gentes enegrecidas" -, constituiu uma espécie de marco zero para negociações identitárias e para eventuais projetos contra-hegemônicos ${ }^{20}$.

Ao mesmo tempo, é inegável que no candomblé articulam-se signos e significados que podem ser relacionados com uma proveniência africana. Estudos históricos e antropológicos, como a importante obra de Luis Nicolau Parés (A formação do candomblé, 2006), vinculam a fundação das primeiras casas de candomblé na Bahia ao calundu (cf. a seguir), que, por sua vez, é relacionado com práticas culturais da África Centro-Ocidental. E há também quem defenda a ideia de que existe uma espécie de substrato de religiosidade/cultura afro-(luso)-brasileira que teria começado a se formar já no início da colonização ou até já na própria África. Assim, Heywood (2002, p. 112) fala da formação de uma "cultura crioula" ou, ainda, de uma "cultura afro-lusitana" em Angola que, com o transporte maciço de escravos desta região para o Brasil durante o século XVIII, teria se reproduzido em terras brasileiras ${ }^{21}$.

Com a introdução do termo "catolicismo africano", Thornton (2002) salientou, de forma semelhante, processos de fusão que teriam ocorrido no reino do Congo. Ele mostra como a elite congolesa se empenhou pessoalmente na divulgação da fé cristã, motivada pelo anseio em se aproximar da Coroa portuguesa e da Igreja Católica ${ }^{22}$, buscando estabelecer uma poderosa aliança que permitisse fortalecer a sua posição na região. Além disso, chama a atenção para o fato de que os padres que atuavam no Congo buscavam semelhanças nas crenças religiosas locais para aproveitá-las no seu trabalho missionário. Assim, usariam a palavra local "nkisi", que de-

${ }^{20}$ Para um aprofundamento dos desdobramentos da história do conceito de negro, cf. Hofbauer (2006).

${ }^{21}$ Heywood relata, entre outros, o caso de uma escrava que tinha vivido seus primeiros 13 anos em Luanda antes de ser vendida ao Brasil (Sabará). De Angola, ela teria levado consigo conhecimentos de adivinhação e de cura - que Heywood descreve como uma combinação entre rituais católicos e africanos - e, por tais práticas, ela viria a ser presa e teria de se defender diante da Inquisição (HEYWOOD, 2002, p. 112).

22 É documentado, p. ex., que o rei do Congo, D. Afonso I, enviou um dos seus filhos (D. Henrique) para Lisboa a fim de que fosse ordenado padre e indicado como primeiro "bispo negro africano" (1518); que o mesmo rei solicitou de Roma uma bula de cruzada (1520) para que as suas guerras na região pudessem ser reconhecidas como atos de divulgação da fé católica, e que vários nobres congoleses tornaram-se membros da Ordem de Cristo. 
signava os objetos sagrados congoleses, para explicar à população a ideia da cruz cristã, e "igualavam" nas suas traduções a figura do "padre" à do "nganga", que se referia ao líder espiritual local ${ }^{23}$. Thornton entende que, em pouco tempo, grande parte dos congoleses começava a se ver, de fato, como cristã, e o Congo se tornava um centro de expansão da fé cristã na região (THORNTON, 2002, p. 84-85). Embora reconheça que se tratava de um cristianismo sincrético e não negue que os congoleses tenham conservado a crença de que os ancestrais mortos continuariam povoando e influenciado o mundo dos vivos ${ }^{24}$, este historiador tem sublinhado a proximidade entre Portugal e o reino do Congo não somente no que diz respeito à concepção do mundo (sobreposição entre sagrado e profano), mas inclusive também no que diz respeito a aspectos importantes das suas estruturas social e política (THORNTON, 1981, p. 188).

Se no discurso hegemônico português o reino do Congo tornar-se-ia uma espécie de prova de que "até" povos africanos poderiam tornar-se "bons cristãos”, os congoleses encontravam nos rituais cristãos um novo repertório de signos por meio dos quais podiam vivenciar e expressar concepções elementares da sua religiosidade. Foi essa avaliação que levou MacGaffey (1994) a afirmar que a relação entre Portugal e o Congo se baseava num profundo mal-entendido, que ele caracterizaria como um "diálogo entre surdos". Concordando com a visão de MacGaffey, Sweet lembra a grande popularidade do batismo com sal no reino do Congo que, de acordo com ele, teria sido concebido pelos africanos como o "símbolo principal da sua condição cristã" (SWEET, 2003, p. 195). O historiador sugere que os congoleses viam nessa cerimônia, pela qual ansiavam passar repetidas vezes, a essência da bruxaria e das forças espirituais europeias, das quais queriam se apropriar. Concebiam-na como mais uma maneira de proteger-se de malevolências, e não como um ritual de purificação de pecados necessário para obter a salvação eterna.

No seu livro Recreating Africa (2003), Sweet polemiza contra a visão segundo a qual o transporte ao Novo Mundo e a vida em escravidão teriam forçado os negros a "abandonar a maior parte do seu passado africano espe-

${ }^{23}$ O uso de tais termos ("nkisi", "nganga") consta também das primeiras traduções de catequese para o kikongo (1556) e o kimbundu (1642), assim como em outros textos elaborados especialmente para fins de missão.

${ }^{24}$ Neste aspecto, Thornton localiza o maior hiato teológico entre o cristianismo e a cosmovisão congolesa. 
cífico e criar 'sociedades escravas' crioulizadas totalmente novas" (SWEET, 2003, p. 115). Baseando-se num exaustivo estudo de documentos históricos, ele procura mostrar contrariamente que, no século XVII e início do século XVIII, as práticas religiosas provenientes da região do Congo e de Angola se mantiveram muito vivas no Brasil ${ }^{25}$. Como na África, cabia aos especialistas religiosos, que teriam seguido os princípios cosmológicos "bantus" do explicar, do prever e do controlar, descobrir os "causadores espirituais" de doenças e de sofrimentos "inexplicáveis" e, de maneira geral, atuar no sentido de atenuar e mediar conflitos sociais (SWEET, 2003, p. 119). Só raramente os senhores teriam se oposto às práticas dos curandeiros e adivinhos; ao contrário, teriam buscado aproveitá-las em favor de seus próprios interesses, $\mathrm{p}$. ex., para localizar um escravo fugido ou um objeto valioso que tivesse sido roubado. De acordo com esse autor, tal ritual, promovido para resolver um certo problema, costumava indicar como "culpado" um negro que não pertencia à comunidade escrava do senhor. A conclusão de Sweet é, portanto, a seguinte: embora os adivinhos tivessem total controle sobre as suas práticas religiosas, muitos "vereditos ritualísticos", que se orientavam pelo princípio da mediação e da manutenção do equilíbrio, contribuíram, de certo modo, para estabilizar a instituição da escravidão (SWEET, 2003, p. 120). O fato de a concepção do mundo "bantu" não permiter separar facilmente as forças religiosas em boas e más ajuda, de acordo com a análise de Sweet, a explicar como as práticas ritualísticas de um determinado especialista religioso podiam ora contribuir para que o senhor reencontrasse um objeto valioso que lhe fora substraído, ora culminar num grande infortúnio para toda a família do senhor.

No fim do século XVII, pode-se perceber um aumento de processos inquisitoriais contra o chamado calund $u^{26}$, que unia o elemento da possessão (incorporação de espíritos) com o da adivinhação e da cura. Os conheci-

${ }^{25}$ Escreve Sweet: "Tais crenças africanas constituíam sistemas independentes de pensamento que caminhavam em paralelo e contra o catolicismo, desafiando o poder temporal da sociedade dominante e deixando a marca indelével da África Central na nação brasileira emergente" (SWEET, 2003, p. 230). E ainda: "Em termos filosóficos e estruturais, a cultura escrava brasileira do século XVII deve ser caracterizada como essencialmente centro-africana, sendo que uma variedade de práticas e crenças étnicas específicas - ndongo, ndembu, kongo, mbata etc. - repercutia no interior da comunidade escrava, de maneira muito parecida como na África Central" (SWEET, 2003, p. 228; tradução do autor).

${ }^{26}$ É provável que o nome calundu derive etimologiamente da palavra do kimbundo "kilundu", que era usada para se referir a vários tipos de espíritos capazes de afetar seres humanos. No Brasil, a palavra calundu seria usada também para se falar das cerimônias religiosas durante as quais ocorriam rituais de possessão e de adivinhação (SWEET, 2003, p. 144). 
mentos dos calundeiros, que atuavam de forma independente, sem uma comunidade de culto fixa, atraíam a atenção não somente da população negra, mas inclusive de vários senhores, que começaram a mandar os seus escravos doentes a esses especialistas religiosos. É sabido que, nos anos 1660, até o mosteiro São Bento de Olinda contratou periodicamente curandeiros negros para cuidar das moléstias de seus escravos (SWEET, 2003, p. 145). Cerca de 60 anos mais tarde, um padre carmelita em Salvador, conhecido pelas suas habilidades de exorcismo, também recebia frequentemente escravos para que os tratasse. Diante da Inquisição, admitiu que, após exames cuidadosos, chegava frequentemente à conclusão de que a prática do exorcismo não conseguia desfazer os "feitiços" (calundus) pelos quais tinham sido atingidos, recomendando que fossem encaminhados a um calundeiro (SWEET, 2003, p. 146, 147) ${ }^{27}$. Para Sweet, tanto a prática daqueles religiosos não tão ortodoxos de conduzir pessoas adoentadas a calundeiros quanto a postura da cúpula da Igreja, que via nos ritos a manifestação de uma obra diabólica, contribuíram, em última instância, para que a crença na eficácia dos calundus tenha se consolidado no Brasil.

Como a concepção do mundo centro-africano entendia sofrimento injustificado e riqueza inexplicável como um sintoma de malevolência religiosa, argumenta esse autor, muitos negros teriam relacionado a sua escravização e a exploração econômica com práticas portuguesas de feitiçaria, buscando responder a isso com o seu arsenal espiritual (SWEET, 2003, p. 162, 229-230). Na sua concepção do mundo, violência física não constituía um instrumento tão poderoso quanto a manipulação de forças espirituais, o que explicaria o fato de que boa parte da resistência escrava tinha um teor religioso que, por sua vez, acarretava efeitos bem mundanos. Mesmo que essas práticas religiosas não tenham posto em xeque o sistema escravista como um todo, avalia Sweet, elas minavam o poder senhorial na medida em que impuseram medo de algo que os senhores não conseguiam dominar.

De acordo com Parés (2006), o "surgimento" e a consolidação de um conjunto de práticas ritualísticas que seria chamado de candomblé deveu-se

${ }^{27}$ Calundeiros eram empregados também como "negros de ganho", o que revela que seus serviços podiam gerar uma interessante fonte de renda para os seus donos. A popularização do calundu faria com que cada vez mais brancos procurassem os serviços desses sacerdotes. Sabe-se que, já no início do século XVIII, cada vez mais mestiços e mestiças começaram a atuar como calundeiros. Sweet (2003, p. 218-219) relata até o caso de uma mulher branca na Bahia (em 1694) que teria sido possessa por calundus. 
à confluência de diversos processos sociais, políticos, econômicos e culturais complexos, entre os quais podemos destacar dois fatores: (1) uma reorientação da "extração de escravos" na África que faria com que, a partir do século XVIII, chegassem cada vez mais escravos da África Ocidental (num primeiro momento, da Costa da Mina; mais tarde, a partir de 1770, sobretudo do Golfo do Benin); (2) na Bahia, especialmente em Salvador, onde a presença de negros provenientes da África Ocidental tornava-se cada vez mais notável, crescia também constantemente a porcentagem de libertos e negros livres na população. Seriam essas pessoas, que podiam agir de forma mais independente que a população escrava, as responsáveis pela fundação das primeiras casas de candomblé no início do século XIX ${ }^{28}$.

Os estudos recentes de Parés (2006) revelam que as primeiras comunidades religiosas se constituíram aos poucos em torno de especialistas religiosos africanos que atuavam também como calundeiros (cf. a seguir). E é sabido também que havia, entre os primeiros adeptos do candomblé, vários membros de irmandades negras. Assim, a tradição oral conta que a "matriz" (casa mater) dos três terreiros mais prestigiosos de Salvador (Casa Branca do Engenho Velho) teria sido fundada por mulheres africanas originárias da cidade de Ketu, pertencentes também à Irmandade de Nossa Senhora da Boa Morte da Igreja da Barroquinha ${ }^{29}$. Mesmo que Parés conteste o conteúdo desse mito fundador, não há dúvida a respeito das diversas interligações e imbricamentos entre irmandades e casas de candomblé. Vale a pena, portanto, darmos uma rápida olhada em algumas características das irmandades negras ${ }^{30}$, sobretudo as que possam ter tido um impacto significativo sobre a formação do mundo do candomblé ou sobre aquilo que alguns entendem como uma "religiosidade especificamente negra ou afro-brasileira".

\footnotetext{
${ }^{28}$ No início do séc. XIX, os libertos e livres já constituíam cerca de $30 \%$ a 40\% da população total (nos EUA, nesse mesmo período, somente $6 \%$ da população livre era composta por não-brancos). Para Parés (2006, p. 133), a alta porcentagem desse grupo foi fundamental para a formação dessa religião de matriz africana. Isso porque, diferentemente dos escravos, alguns dos negros libertos e livres conseguiram alugar ou comprar uma casa ou um terreno e, dessa forma, criar a estrutura necessária para aquilo que entendemos hoje como candomblé.

${ }^{29}$ Para Parés (2006), as primeiras casas não podiam ter sido fundadas por africanas ligadas ao reino de Ketu. Ele entende esta narrativa, portanto, como sendo uma construção posterior, já que procura mostrar que o início do candomblé esteve ligado à "tradição jeje" (cf. a seguir).

30 Para análises mais aprofundadas sobre as irmandades negras, cf. p. ex. Scarano (1978); Mulvey (1999); Souza (2002b).
} 
A irmandade negra era vista pelos senhores e pela Igreja como um prático instrumento de catequese que deveria, inclusive, contribuir para o disciplinamento social dos africanos e de seus descendentes no Brasil. Ao mesmo tempo, constituía a única instituição legalizada na qual a população negra podia - mesmo sob a tutela da Igreja - organizar-se, (re)criando e fortalecendo sentimentos de comunalismo ${ }^{31}$. Ao seguirem o princípio medieval de autoajuda (solidariedade grupal), as irmandades ofereciam aos confrades uma espécie de seguro social. Buscavam ajudar os irmãos que estavam em apuros, podiam, em determinadas situações, emprestar-lhes dinheiro ${ }^{32}$, cuidavam daqueles que estavam doentes e, acima de tudo, garantiam um enterro digno (muitas vezes negado pelos senhores) para todos os seus membros ${ }^{33}$.

Marina de Mello e Souza (2002a, p. 145) destaca as "funções" semelhantes que santos católicos e "minkisi" ${ }^{4}$ teriam exercido em seus respectivos contextos originários. Ambos seriam vistos como mediadores entre duas dimensões de mundo, podendo ser invocados pelos vivos que esperam sua ajuda para resolver seus problemas particulares. Já Parés aproxima os calundus aos santos católicos quando afirma que "aos olhos dos africanos" possuíam a mesma eficácia (PARÉS, 2006, p. 111) ${ }^{35}$.

De tempos em tempos, diversas irmandades também foram acusadas de atos de heresia, provavelmente porque vários irmãos eram igualmente adeptos do candomblé. Mulvey afirma que, não raramente, um ou outro

31 Parés destaca a importância das irmandades para a criação da ideia de "parentesco de nação" que, de maneira semelhante, se expressaria nos candomblés sob a forma de "família de santo" (PARÉS, 2006, p. 78). Para um aprofundamento da questão da (re)criação de "nações" nas irmandades e das alianças e conflitos entre elas, cf. p. ex. Reis (1996) e Silveira (2006). Vale lembrar também, nesse contexto, que as irmandades negras não excluíam a participação de brancos. Não raramente, alguns cargos da mesa diretora (sobretudo, as funções de tesoureiro e de escrivão) eram cedidos a homens brancos - na maioria das vezes por não haver negros alfabetizados na confraria.

32 Houve casos em que uma irmandade emprestou dinheiro para que confrades pudessem comprar a sua alforria. No entanto, tal empréstimo era em geral concedido somente quando o escravo podia garantir que devolveria o dinheiro à irmandade.

33 O fato de que em muitas sociedades africanas as cerimônias funerárias representavam a passagem do mundo dos vivos para o mundo dos ancestrais ou dos espíritos da natureza explicaria, de acordo com Mello e Souza, a rápida e maciça adesão dos negros a essa instituição. Segundo essa historiadora, na virada do século XVIII para o século XIX cerca de $80 \%$ da população negra pertencia a pelo menos uma irmandade (SOUZA, 2002b, p. 186, 189).

34 "Minkisi" é a forma plural de "nkisi".

35 Afirma Parés: "A [a]cumulação de recursos espirituais diferenciados, aliás característica de muitas religiões africanas e também do catolicismo popular, não era vivida necessariamente como uma contradição, mas como uma estratégia eficaz para lidar com a adversidade e propiciar boa fortuna" (PARÉS, 2006, p. 111). 
irmão carregava no meio de uma procissão um "fetiche" (MULVEY, 1982, p. 43), de maneira que foram estabelecidos alguns "compromissos" buscando proibir a admissão de pessoas conhecidas como "feiticeiros", assim como outros "estatutos" determinando explicitamente a expulsão daqueles que fossem pegos exibindo "fetiches" em cerimônias religiosas. Mas, de acordo com Parés e com Mello e Souza, mesmo que as irmandades possam ter encoberto "práticas que não se ajustavam aos cânones e [às] regras da teologia católica", não haveria razão para duvidar que boa parte dos negros vivia "um catolicismo sentido como verdadeiro" (PARÉS, 2006, p. 111; SOUZA, 2002b, p. 323).

A figura do rei do Congo e as festas de coroação podem ser entendidas como uma concessão da Igreja e/ou uma conquista da população negra, já que não há nenhuma prática correspondente nas confrarias brancas. Se, por um lado, parte da elite branca associava o nome Congo a um modelo de evangelização, de modo a poder ser entendido como um símbolo de subjugação colonial e de assimilação cultural-religiosa, para muitos negros, por outro lado, o Congo remetia ao poder legendário do rei deste reino. Os reis do Congo, que conferiam às irmandades um sentimento de identidade grupal, atuavam frequentemente como mediadores entre o mundo dos senhores e a população negra ${ }^{36}$.

As eleições e as coroações periódicas dos reis, que envolviam grandes festas, provocaram, durante muito tempo, longas discussões no meio das autoridades e da intelligentsia religiosa. Se em "tempos de paz" tais festividades podiam contar até com o incentivo de certos clérigos, em situações de instabilidade e de conflito enfrentavam diferentes formas de repressão. Silva entende que uma inicial atitude de condescendência "tipicamente barroca" assumida por parte das autoridades cederia, aos poucos, a uma postura que se orientava mais por ideais iluministas e desembocaria na proibição de tais festas, sobretudo com a introdução das reformas pombalinas.

\footnotetext{
${ }^{36}$ Em determinadas situações, os reis conseguiam canalizar uma ou outra reivindicação da comunidade; frequentemente, porém, as autoridades locais buscavam cooptar os reis como parte de uma estratégia de manutenção da ordem social. Num dos seus vários estudos sobre as confrarias negras, Silva chega, assim, à conclusão de que "hierarquias e critérios de estratificação entre os negros", que se expressavam em instituições como os terços de Henriques e Pardos, os governos de nações e de ofícios e as irmandades, "serviam para estabelecer um pacto entre controladores e controlados"; "elas não apenas regulavam as relações entre os escravos e os homens livres de cor, tomados isoladamente do conjunto da sociedade; tais hierarquias também contribuíam para a reprodução da ordem escravista e, em última análise, do antigo regime" (SILVA, s/d, 11).
} 
O historiador apresenta um exemplo emblemático em que o governador da capitania de Pernambuco reage à repressão que os confrades sofreram da parte de quatro missionários italianos que se mostraram chocados com os rituais dos negros e chegaram a destruir seus instrumentos musicais. Num primeiro momento, o governador defende os irmãos da confraria, dando-lhes, inclusive, dinheiro para reconstruir os seus instrumentos. Mas a insistência dos capuchinhos fez com que a discordância se transformasse num grande debate sobre a natureza das danças dos negros de Recife e sobre a melhor maneira de controlar a população escrava ${ }^{37}$. Para resolver a questão sobre se os negros praticavam ritos católicos ou não, o Santo Ofício solicitou do Conde de Povolide um julgamento final. No seu parecer (1780), este diferenciaria entre dois tipos de festas: (1) “danças supersticiosas" - comparáveis aos "fandangos de Castela" e às "fofas de Portugal" - que, na avaliação do Conde, não precisariam ser reprimidas totalmente, ainda que "não sejam as mais Santas"; e (2) aqueles "bailes" "que os Pretos da Costa da Mina, fazem às escondidas, ou em Casas, ou Roças, com uma Preta Mestra, com Altares de Ídolos adorando Bodes vivos, e outros feitos de Barro, untando seus corpos com diversos óleos, sangue de galo, (...)" (in: SILVA, 2005, p. 278-9; cf. tb. SOUZA, 2002b, p. 232), que mereceriam "total reprovação". A descrição de tais cerimônias, nas quais o Conde de Povolide não conseguia e/ou não queria identificar mais nenhum elemento católico, aponta para traços ritualísticos que sugerem certa semelhança com algumas práticas religiosas que se cristalizariam nos terreiros de candomblé.

\section{Pureza religiosa-cultural como estratégia de defesa e de combate}

No seu livro A formação do candomblé, Parés (2006) argumenta que o fenômeno que hoje entendemos como candomblé começou a se articular no momento em que alguns calundeiros criaram, paralelamente às suas atividades individuais como adivinhos e curandeiros, comunidades religiosas incipientes em Salvador. Sem necessariamente abandonarem, num primeiro momento, as suas "carreiras" como calundeiros, teriam criado as primeiras estruturas eclesiásticas em torno da veneração de, inicialmente, uma divin-

\footnotetext{
Para o governador, as danças não conservavam elementos de ritos gentílicos, sendo muito mais uma maneira não tão diferente daquela dos brancos de expressar a fé católica. Além disso, entendia que a concessão daqueles divertimentos aos domingos poderia prevenir a explosão de distúrbios, de maneira que, para ele, constituía uma "razão de Estado" não proibir tais festas.
} 
dade e, posteriormente, de uma pluralidade de divindades, estruturas essas que exigiam daqueles que quisessem participar da comunidade a submissão a longos processos de iniciação ${ }^{38}$.

Baseando-se em análises demográficas, etimológicas e antropológicas, Parés defende a ideia de que a fundação das primeiras casas de candomblé deve-se não a africanos provenientes da "iorubalândia" - amplo consenso entre os estudiosos até pouco tempo -, mas a africanos "jejes" 39 . Seu primeiro argumento refere-se a um crescimento da porcentagem dos jejes na população escrava em Salvador a partir da primeira metade do século XVIII (PARÉS, 2006, p. 68). Além disso, Parés chama a atenção para o fato de que a maioria das palavras que dizem respeito a detalhes das práticas ritualísticas do candomblé, registradas no início do século XIX, aponta para uma raiz etimológica jeje $\mathrm{e}^{40}$. Em sua análise, Parés destaca ainda uma tendência

38 Parés relaciona tal desenvolvimento com a articulação de "um progressivo nível de complexidade social e ritual". Escreve o autor: "De um estágio inicial, em que 'fragmentos de cultura religiosa' foram retomados e postos em prática por pessoas carismáticas que atuavam de uma forma relativamente individual e independente (em interações pessoais, visando principalmente a fins de cura e adivinhação), passou-se pela formação das primeiras congregações religiosas de caráter familiar ou doméstico, geralmente dedicadas ao culto de uma só divindade, até se chegar à formação de congregações extrafamiliares, socialmente ainda mais complexas nas suas estruturas hierárquicas e práticas rituais, que com o tempo chegaram a funcionar com certa estabilidade em espaços próprios, com calendário litúrgico recorrente e dedicadas ao culto de uma pluralidade de divindades,'assentadas'em altares ou espaços sagrados individualizados"(PARÉS, 2006, p. 118). Se as "práticas de cura e feitiçaria" do calundu se concentravam na produção de amuletos, patuás, bolsas de mandinga, i.é., em "objetos móveis, individualizados ou personificados, concebidos como instrumentos mediadores para a obtenção de algum fim (...)", a articulação daquilo que Parés descreve como "sistema altar-oferenda" (ou "complexo assento-ebó") teria provocado "um salto qualitativo": "Os assentos ou altares são 'complexos materiais sacralizados' relativamente fixos (enterrados, muitas vezes) e de propriedade familiar ou coletiva; concebidos como habitat ou residência de divindades nomeadas e bem definidas, que comportam normalmente a iniciação de devotos. A minha hipótese", continua Parés, "é que foi a partir das tradições da Costa da Mina que, no séc. XVIII, começaram a se organizar alguns calundus que iam além da mera funcionalidade de cura e adivinhação, sem, no entanto, prescindir delas" (PARÉS, 2006, p. 116).

39 O uso do termo "ioruba" para essa época é, como veremos a seguir, anacrônico. Na região hoje identificada como "iorubalândia" existiam diferentes "reinos" (cidades-estados) que criaram alianças e/ou viveram em conflito entre si. O termo"jeje", usado somente no Brasil, tornar-se-ia praticamente sinônimo para aqueles africanos que viviam sob a influência do reino Daomé (dominado e controlado pelo grupo fon), que mantinha relações tensas com Oyo (reino "iorubano"mais importante no séc. XVIII). Se Parés busca a origem etimológica desse termo numa palavra usada para designar um subgrupo dos adja e/ou todos aqueles escravos traficados por comerciantes lusófonos do forte de Ouidá (situado na área linguística gbe, à qual pertencem adja, fon e outras línguas) para o Brasil (PARÉS, 2006, p. 4749), Matory vê na palavra jeje em primeiro lugar um exemplo paradigmático da formação de novas identidades no diálogo transatlântico (MATORY, 1999, p. 57-80).

${ }^{40}$ Assim, os documentos mais antigos não falam de orixás (termo iorubano), mas registraram o uso do termo jeje (gbe) "voduns" para se referir às divindades. Da mesma forma, não aparece nos textos a palavra "Exu", mas o seu "nome correspondente" em fon, "Legba". Muitos termos que se referem a 
particular dos jejes - desconhecida entre outros grupos, como p. ex. os iorubas -, que seria a de incluir, assimilar e agregar novas divindades e, dessa forma, criar um panteão de deuses, uma das características mais notáveis do candomblé (PARÉS, 2006, p. 272).

Quando - na virada do século XVIII para o século XIX - passaram a chegar grandes contingentes de escravos iorubas, explica Parés, os jejes perderam em "visibilidade", e suas tradições culturais foram, de certa maneira, "incorporadas" pelos iorubas ${ }^{41}$. Teria ocorrido um processo de trocas e interpenetrações culturais mútuas, de maneira que, por volta de 1860, já se formavam as práticas religiosas que Nina Rodrigues chamaria de "cultos jejes-nagôs ${ }^{42 "}$.

Parés lembra ainda que a ascensão e a consolidação do candomblé na Bahia coincidiram com o momento em que - a partir da segunda metade do século XIX - decresce a importância das irmandades negras como instrumento de agregação e organização da população negra (PARÉS, 2006, p. 138). E, com a popularização do termo "candomblé" 43 , a palavra "calundu" teria sido cada vez menos usada para designar práticas ritualísticas de origem africana.

Partindo das premissas da perspectiva do Atlântico Negro, o antropólogo norte-americano Lorand Matory, por sua vez, atribui o sucesso da "cultura iorubana" em toda a América à atuação dos chamados "negros" retornados, ou seja, daqueles ex-escravos que voltaram para a África. Um papel de destaque tiveram os libertos oriundos da "iorubalândia" que, depois de terem sido formados em escolas missionárias em Freetown (Serra Leoa) ${ }^{44}$, voltaram para Lagos, onde trabalharam como missionários, comerciantes ou na administração colonial. Foram eles (sobretudo pastores diaspóricos negros) os primeiros a fazer registros da história, da língua e das tradições locais, além de terem elaborado as primeiras traduções da Bíblia. Para isto, os missionários-tradutores precisaram elaborar um "padrão linguístico", o

práticas ritualísticas fundamentais de todas as casas de candomblé (independentemente da "nação"à qual pertencem) teriam até hoje uma raiz etimológica jeje: p. ex., os atabaques sagrados (rum, rumpi, lé); o quarto de reclusão dos iniciados (runcó); o "altar sagrado" (peji) etc. (PARÉS, 2006, p. 144-146).

${ }^{41}$ Parés descreve situações de conflito em que negros jeje se diziam iorubas, ou seja, buscavam identificarse com o grupo numericamente mais importante naquele momento. Alguns jejes aparentemente já tinham aprendido a língua ioruba na África.

42 No Brasil, o termo "nagô" se tornaria sinônimo para "ioruba".

${ }^{43}$ O registro mais antigo - até hoje - da palavra "candomblé" data de 1807 (PARÉS, 2006, p. 126)

${ }^{44}$ Antes da fundação da cidade de Freetown, em 1787, concebida para receber libertos, não existia um termo específico para designar aqueles africanos que hoje são chamados de iorubas. 
que, de acordo com Matory, contribuiu de forma decisiva para homogeneizar os dialetos locais e criar uma espécie de "standard ioruba"45.

Por volta de 1890, parte dessa elite negra burguesa que vivia em Lagos sentia-se discriminada pela política colonial britânica e acompanhava, com interesse, as lutas dos negros nos EUA contra as leis segregacionistas de Jim Crow; formou um movimento de cunho nativista, que seria chamado de "Renascimento Lagosiano". De acordo com Matory, foi nesse contexto histórico que se articulou e se consolidou a noção da "pureza iorubana" ("pureza nagô"), que incluía a ideia da "superioridade" dos iorubas em relação a outros grupos. Num diálogo com outras diásporas negras (sobretudo a norte-americana), essa intelligentsia local teria reagido a experiências de humilhação e discriminação com a produção de representações idealizadas e essencialistas das tradições locais “iorubanas”. Tal elite, que se via como cristã, não chegou a propagar a religião dos orixás nos seus escritos, mas prezava os "cultos iorubanos" como uma herança valiosa dos seus ancestrais. De acordo com Matory, esses textos criaram uma primeira codificação cultural-religiosa que podia ser apropriada e reinterpretada por seguidores ("descendentes iorubanos") nos dois lados do Atlântico (MATORY, 2005, p. 64).

Nesse contexto, Matory chama a atenção para o fluxo de viajantes negros que existiu entre a Bahia e o litoral ocidental da África (Nigéria e Benin atuais). Não somente objetos religiosos e notícias circulavam. Matory cita vários líderes religiosos importantes que viajavam. Assim, p. ex., Martiniano Eliseu do Bonfim ${ }^{46}$, filho de libertos africanos, passou onze anos (1875-1886) em Lagos, onde não somente frequentou uma escola presbiteriana, mas foi também iniciado no sacerdócio de Ifá. De volta à Bahia, introduziu elementos ritualísticos que conheceu na África (12 obás de Xangô) no Ilê Axé Opô Afonjá, ao qual estava ligado. Teria, portanto, importante influência sobre as práticas religiosas nessa prestigiosa casa e tornar-se-ia ainda informante principal do "pai" dos estudos afro-brasileiros, Nina Rodrigues.

45 Assim, Samuel Ajayi Crother, primeiro bispo africano da Igreja Anglicana, escreve não somente um dicionário da língua ioruba (1843) e uma gramática ioruba (1852), mas edita também, juntamente com Samuel Johnson, uma tradução da Bíblia.

${ }^{46}$ Uma outra personagem importante foi Felisberto Sowzer, que atuava como babalaô, era também maçom e se orgulhava de seus "hábitos britânicos". Outra ainda foi Lourenço Cardoso, comerciante de Lagos, que trabalhava como professor de inglês em Salvador e ajudou Nina Rodrigues a traduzir textos escritos em ioruba. Teria sido ele quem chamou a atenção do eminente pesquisador para a importância do livro The Yoruba-speaking peoples of the slave coast of West Africa, de A. B. Ellis (1894). 
Com essas análises, Matory procura mostrar que foram africanos e seus descendentes, ligados a um movimento literário transnacional (Renascimento Lagosiano), que contribuíram tanto para codificar e reificar aquilo que hoje entendemos como cultura iorubana quanto para disseminá-la. De um lado, esse cientista procura combater a visão antropológica clássica que concebe as religiões afro-americanas como "sobrevivências" de determinadas tradições culturais; de outro, opõe-se também explicitamente àquela interpretação segundo a qual a noção da "pureza nagô" se deve, em primeiro lugar, à intervenção de intelectuais locais, caracterizados por esse pesquisador negro norte-americano como eurobrasileiros (MATORY, 1998, p. 267). Se Matory critica, com razão, que tais explicações, como aquela apresentada pela primeira vez pela antropóloga Góis Dantas em $1988^{47}$, omitem o papel ativo de negros africanos na construção da valorização da "tradição nagô", parece ser, ao mesmo tempo, inegável que houve uma participação ativa da parte de pesquisadores brasileiros no combate a discriminações, perseguições policiais e criminalização do candomblé. Uma das "estratégias analíticodiscursivas" usadas por intelectuais que se aproximavam dos terreiros foi justamente o enaltecimento do modelo nagô ("nação ketu”) em detrimento de outras práticas ritualísticas (nações), avaliadas como menos autênticas e/ou "misturadas" (como p. ex. os candomblés de angola e de caboclo) ${ }^{48}$.

Estudos mais recentes mostram também que a relação entre o candomblé e o "mundo branco" foi provavelmente mais ambivalente do que os estudos

47 Ordep Serra opõe-se igualmente à análise de Dantas: para ele, "preocupações com a ortodoxia, a pureza ritual, a fidelidade às origens" não são invenções de intelectuais, mas fazem, há muito tempo, parte do mundo do candomblé (SERRA, 1995, p. 112-115).

48 Um papel importante nesse processo coube aos congressos afro-brasileiros (1934, em Recife; 1937, em Salvador). Um dos objetivos desses eventos foi a elaboração de estratégias que permitissem conquistar maior aceitação do candomblé na sociedade nacional. Na medida em que os idealizadores dos congressos enalteciam a "nação ketu" como "tradição pura" e "verdadeira religião", com o objetivo de reivindicar o cumprimento do direito à prática livre de todas as confissões religiosas, garantida pela Constituição, foram criando discursos que desvalorizavam as práticas de outras nações. Já Nina Rodrigues, baseando-se em suas "convicções evolucionistas-raciais", expressava sua admiração para com o "estado de admirável pureza" das "sobrevivências morais africanas" detectadas nos terreiros jejes-nagôs, e usava tal avaliação como argumento para combater a perseguição policial. Se, do ponto de vista teológico (católico), "as práticas religiosas dos nossos negros podem (...) ser capitulad[a]s de um erro", escreve, "[a]bsolutamente elas não são um crime, e não justificam as agressões brutais da polícia, de que são vítimas" (RODRIGUES, 1977, p. 246). É importante lembrarmo-nos, nesse contexto, que em 1890, i.é., dois anos após a abolição, o Código Penal (art. 157) passou a criminalizar práticas de "curandeiros", "feiticeiros", "espiritistas" e "cartomantes", e que, na Bahia, a lei que obrigava as casas de candomblé a ter um registro na Delegacia de Jogos e Costumes junto à Secretaria de Segurança Pública foi revogada somente em 1976. 
clássicos (Nina Rodrigues, Roger Bastide) - mas também as análises de Matory - sugerem. Sabemos hoje que, já no século XIX, os terreiros acolhiam pessoas de diferentes tonalidades de cor/características fenotípicas e pertencentes a diferentes status sociais. Segundo os estudos de Harding (2000, p. 72), até meados do século XIX, cerca de 90\% dos líderes religiosos eram pessoas nascidas na África; mas, em pouco tempo, cada vez mais crioulos, assim como mestiços e, inclusive, alguns brancos começaram a chefiar casas de candomblé. Se era incomum que negros escravos liderassem os terreiros, havia, sim, um grande número de cativos entre aqueles que procuravam os candomblés ${ }^{49}$.

O fato de a polícia ter encontrado com certa frequência, nas suas investidas nos terreiros, pessoas que pertenciam a camadas sociais elevadas, incomodava não somente a elite branca. Havia um grupo de abolicionistas negros que se reunia em torno de uma revista (Alabama, 1863-1900), que fazia uma campanha sistemática contra os rituais do candomblé. Nos seus artigos, esse grupo denunciava repetidamente a presença de advogados e policiais nos terreiros, fato que revela que algumas comunidades de terreiro mantinham aparentemente boas relações com pessoas influentes da sociedade soteropolitana. Sabe-se também que, em alguns casos, as pessoas brancas ligadas aos candomblés intercederam junto às instituições legais em defesa dos terreiros ${ }^{50}$. A invenção da figura do "ogã" ${ }^{1}$ - um cargo masculino que tem como função principal a representação da congregação religiosa diante da sociedade civil - deveu-se, portanto, de acordo com Parés (2006, p. 132), à necessidade de criar estratégias eficazes de autodefesa do grupo.

No centro das práticas religiosas dos candomblés se encontrava a invocação das divindades africanas. Dependendo das "nações” (ketu, jeje, angola), cultiva(va)m-se orixás, voduns ou inquices. Ao mesmo tempo, ocorreram adaptações de diferentes ordens, como, p. ex., a adaptação ao calendário católico. Há diversos orixás que são até hoje celebrados em dias em que a Igreja Católica festeja um "santo correspondente". Ocorreram "aproximações" tanto entre histórias míticas cristãs e africanas quanto entre santos católicos

${ }^{49}$ De tempos em tempos, alguns terreiros eram acusados de esconder escravos fugitivos.

50 Parés (2006, p. 132) cita o caso de um procurador branco - Joaquim José de Oliveira - que buscava, recorrentemente, conseguir a soltura de negros que a polícia prendia nas suas investidas nos terreiros.

51 Vários importantes pesquisadores responsáveis pelos primeiros estudos sobre o candomblé foram ogãs. Nina Rodrigues e Arthur Ramos ocuparam o cargo de ogã no Gantois, e E. Carneiro foi ogã no llê Axé Opô Afonjá. 
e orixás, como, p. ex., entre São Jorge e Ogum, sendo o primeiro lembrado na tradição ocidental como soldado romano e, ainda mais frequentemente, como matador de dragões e padroeiro dos ferreiros, enquanto o segundo, Ogum, é lembrado como divindade do ferro e da guerra ${ }^{52}$. Além disso, tornou-se costume em vários terreiros levar o/a recém-iniciado/a (iaô) a uma igreja para assistir a missa e entregar os mortos à religião hegemônica, o catolicismo ${ }^{53}$.

Adaptações como essas se explicam talvez pelo fato de que a Igreja Católica constituiu durante muito tempo fonte de legitimação social. Sobretudo ex-escravos, que ansiavam ascender socialmente, tinham de declarar-se - "representar-se" - católicos e participar dos ritos católicos públicos. E, aparentemente, vários dos fundadores das primeiras casas de candomblé assumiram igualmente essa "estratégia sociorreligiosa". Sabe-se, p. ex., que mesmo uma personagem como Martiniano do Bonfim, que já se mostrava muito preocupado com a "preservação da tradição iorubana" e criticava a "decadência religiosa" que ele constatava em diversas casas de candomblé na Bahia, dizia-se católico e frequentava regularmente, de fato, a "sua" igreja São Jorge.

\section{A caminho de uma nova religião mundial?}

Muitas coisas mudaram no mundo do candomblé e no que está à sua volta desde a época de Bonfim, que faleceu em 1943 na Bahia. O candomblé disseminou-se sobre quase todo o território brasileiro. Foi por meio de migrantes nordestinos que o candomblé chegou aos centros urbanos do sudeste; mais tarde, atravessaria fronteiras e mares e conquistaria ainda o espaço cibernético. Os vários esforços visando descriminalizar o candomblé e consolidá-lo como uma religião como todas as outras contribuíram para que cada vez mais pessoas de classe média e até mesmo alta - a maioria delas não-negras - se aproximassem do candomblé, de maneira que há quem avalie

\footnotetext{
52 Até que ponto a relação entre santos católicos e orixás representa uma correspondência analógica, uma sobreposição (disfarce) ou mesmo uma fusão é uma questão que faz parte intrínseca dos processos de construção e desconstrução de diferenças e significados (cf. texto a seguir). Palmié, p. ex., tem argumentado (nas suas análises sobre a regla ocha/santería) que, mesmo que haja semelhanças entre orixás e santos católicos, nenhum "santero" sacrificaria um animal para a imagem do santo. É o "assentamento" que propicia o acesso ao orixá, enquanto a imagem do santo católico simbolizaria "somente" seus atributos (PALMIÉ, 1995, p. 82).

${ }^{53}$ A tradicional cerimônia fúnebre, axexê, é geralmente promovida somente para pessoas de alto prestígio religioso (ebomis que têm filhos de santo).
} 
que a partir da década de 1960 o candomblé já não pode ser considerado uma "religião étnica" (PRANDI, 1996a, p. 39, 72; PRANDI, 2000, p. 86) 54.

Sociólogo de religião e especialista em pesquisas sobre o candomblé, Reginaldo Prandi avalia ainda que no fim do século XX todas as religiões começaram a passar por um processo de profunda transformação. A religião teria perdido "a prerrogativa de explicar e justificar a vida", já não conseguiria gerar coesão social, e a sua importância estaria "passando pouco a pouco para o território do indivíduo". Para Prandi, a velha religião - "fonte de transcendência para a sociedade como um todo" - foi estilhaçada, e o novo tipo de religiosidade que estaria se impondo seria uma religião voltada para causas localizadas e reparos específicos (PRANDI, 1996b, p. 67, 77). De acordo com essa análise, o capitalismo avançado já penetrou na lógica de organização das religiões, que agora competem entre si pela adesão de "clientes" 55 . Nessa situação, os adeptos assumiriam, cada vez mais, um comportamento consumista em relação às suas experiências religiosas ${ }^{56}$.

Nem todo mundo concorda, evidentemente, com essa visão sociológica clássica que projeta um processo de contínua secularização. Enquanto alguns pesquisadores defendem, de fato, a ideia de que estamos assistindo, no mundo contemporâneo, a um reflorescimento do fenômeno religioso, outros especialistas já são mais cautelosos e procuram fazer uma diferenciação. Assim, Peter Berger, p. ex., afirma que a modernidade não é necessariamente secularizante, mas sim necessariamente pluralizante. Ela se destacaria não pela ausência de Deus, mas pela presença de uma multiplicidade de divindades. Haveria, porém, duas exceções: uma seria geográfica e se restringiria à Europa central e ocidental, onde Berger localiza a formação de uma postura que

${ }^{54}$ Segundo o Censo de 2000, "somente" 22,8\% dos adeptos do candomblé declarou a sua cor/raça como "preta" (no mesmo censo, 6,2\% da população brasileira total definiu-se como "preta"). A comparação desses dados com aqueles de outras religiões indica que o candomblé continua sendo a religião com a maior participação de "pretos" (PRANDI, 2003, p. 31).

55 "Por isso", escreve Prandi,"se enganam os que imaginam que vivemos um momento de grande reflorescimento religioso, que nega a secularização e leva a sociedade, de novo, a entregar os pontos ao sagrado" (PRANDI 1996b, p. 76).

${ }^{56}$ Para Prandi, o fato de que as pessoas passam hoje frequentemente de uma religião para outra seria uma expressão dessa "atitude individualista e consumista". De acordo com esse pesquisador, na década de 1990, uma entre dez pessoas na Grande São Paulo mudava a sua religião num prazo de um ano. (PRANDI, 1996b, p. 68-70, p. 76-77). Poucas décadas atrás, conversões consecutivas desse tipo eram raras e podiam provocar conflitos intrafamiliares e rupturas na vida da pessoa. Prandi mostra que motivações pragmáticas (a busca de soluções para problemas individuais) para conversões são hoje relativamente bem aceitas, uma vez que pertencer a uma religião é tido como uma questão de escolha pessoal (PRANDI, 2003, p. 27). 
denomina de "eurosecularity"; e a outra diria respeito a uma "elite cultural internacional" secularizada, "produto" da globalização da intelligentsia ilustrada da Europa, que formaria, em qualquer lugar do globo, uma - porém, muito influente - minoria. Se o pluralismo religioso não é, evidentemente, um fenômeno totalmente novo, segue a argumentação desse cientista, o seu escopo e a sua intensidade não teriam nenhum precedente na história. Seria essa nova qualidade de pluralismo que constitui, de fato, um desafio para todas as religiões (BERGER, 2008, p.1-2).

Num cenário em que a mídia ganha cada vez mais importância na divulgação de conteúdos religiosos, avaliam Prandi e outros pesquisadores, as religiões de matriz africana têm perdido terreno. As pequenas comunidades (raramente mais de 50 pessoas), que possuem plena autonomia administrativa, ritual e doutrinária e se entendem como "famílias de santo" 57 , têm grande dificuldade para se proteger dos ataques agressivos das igrejas neopentecostais, que apresentam diariamente, em canais de televisão controlados por elas, cenas de exorcização de "entidades religiosas afro-brasileiras" (Exus, Pombagiras $^{58}$ ) e procuram, dessa forma, afastar as pessoas das religiões afrobrasileiras e convertê-las ao neopentecostalismo.

As estatísticas oficiais indicam que nas últimas décadas houve, de fato, um recuo do número de praticantes de religiões de matriz africana. Se em 1980 as religiões afro-brasileiras constituíam 0,6\% do espectro religioso, em 2000 formaram somente $0,3 \%$ de todas as religiões no Brasil ${ }^{59}$. Nesse contexto, é importante lembrar que muitos adeptos do candomblé e da umbanda evitam, por causa das frequentes hostilidades e discriminações, admitir sua relação com essas religiões, preferindo declarar-se católicos. Quando se examina os dados estatísticos, percebe-se que foi a umbanda a religião afro-brasileira que

57 Há uma relação de respeito especial com a casa na qual o/a líder religioso/a foi iniciado/a, que constitui, de certa maneira, "fonte do conhecimento religioso". Formas de organização supraterreiros não estritamente religiosas são raras; existem diversas federações cuja eficácia organizatória e política é não raramente questionada pelos próprios adeptos. Além disso, alguns líderes organizam, de tempos em tempos - frequentemente em parceria com autoridades locais, universidades, movimentos negros, ONGS -, seminários e congressos em que os adeptos debatem tanto questões relacionadas com a vivência dentro das casas, quanto a relação com outras religiões e temáticas como discriminação e racismo.

${ }^{58}$ Desde o início da intervenção europeia na África Ocidental, a divindade Exu (princípio da dinâmica e da sexualidade, representado frequentemente como um falo ereto) foi associada pelos colonizadores com o diabo. A Pombagira pode ser entendida como um Exu feminino que se manifesta em rituais da umbanda.

59 De acordo com essas estatísticas, as religiões afro-brasileiras perderam entre 1980 e 2000 cerca de cem mil adeptos. A maioria aparentemente converteu-se a religiões (neo)pentecostais (PRANDI, 2003, p. 18). 
mais perdeu adeptos, enquanto o número dos candomblecistas aumentou consideravelmente ${ }^{60}$. E o que chama mais a atenção nessas análises quantitativas é o fato de que, dentro do espectro do candomblé, são os terreiros que se dizem (re)africanizados que mais têm crescido nos últimos tempos.

Pode-se constatar que, a partir da década de 1980, diversas lideranças religiosas começaram a sentir necessidade de introduzir reformas nas práticas e nas tradições ritualísticas. Nos seus posicionamentos, articulados em congressos, em forma de textos e/ou ainda em sites na internet, essa pequena elite de líderes religiosos costuma delimitar o candomblé, por um lado, do catolicismo, e, por outro, da umbanda, cujas práticas são geralmente vistas como "sincréticas", ou seja, não "puramente africanas". Vimos que o enaltecimento da "pureza ritualística" não é um elemento novo, mas há muito tempo constitui um argumento importante nas disputas por prestígio e poder no mundo do candomblé. Assim, Bonfim entendeu a introdução dos 12 obás de Xangô no cotidiano ritualístico do Ilê Opô Afonjá também como uma adaptação ao "modelo africano", mas - diferentemente da tendência atual - tal "inovação" ou "correção da tradição" não punha em xeque a presença dos santos católicos expostos nos nichos do templo. Contrário a essa postura de Bonfim, a mãe de santo atual do Opô Afonjá encontra-se entre os mais ferrenhos críticos de associações e fusões entre religião africana e catolicismo. Mãe Stella, uma das ialorixás mais respeitadas da atualidade, assinou em 1983, na ocasião da Segunda Conferência Mundial da Tradição Orixá e Cultura, que ocorreu em Salvador, uma espécie de manifesto contra o sincretismo.

Nesse documento, a origem do fenômeno do sincretismo é interpretada como uma estratégia de sobrevivência que teria sido imprescindível na época da escravidão; nos tempos modernos, porém, teria perdido a sua razão de ser. Como tais "misturas" com o catolicismo distorceriam o caráter verdadeiro da religião africana, avalia o texto, seria necessário abandoná-las. Somente dessa maneira seria então possível "devolver ao culto dos Orixás, à religião africana a dignidade perdida durante a escravidão" e fazer frente a processos degradantes, como tendências de alienação cultural e econômica, folclorização e profanação (in: CAMPOS, 2003, p. 44-48; cf. tb. CONSORTE, 1999, p. 90$)^{61}$.

60 Se em 1991, 107 mil pessoas se diziam adeptas do candomblé, em 2000 foram 140 mil, o que significa um aumento de mais de 30\%. No ano de 1991, os candomblecistas constituíam 16,5\% dos adeptos das religiões afro-brasileiras; já em 2000, atingiram 24,4\% nessa categoria de religiões (PRANDI, 2003, p. 21).

${ }^{61}$ Um estudo de Consorte (1999, p. 84) feito quinze anos depois dessa proclamação (1998) revelou, porém, que, com exceção do llê Axé Opô Afonjá, liderado por Mãe Stella, as práticas ritualísticas nos 
A mudança de atitude que pode ser detectada através dessas palavras condiz também com ideias que foram desenvolvidas dentro dos movimentos negros, que, sobretudo desde o processo de redemocratização, têm salientado a importância simbólica e política das "raízes culturais negras" na luta contra o preconceito e o racismo ${ }^{62}$. Se a partir da década de 1970 e, sobretudo, na última década desse milênio, mais e mais militantes negros aproximaram-se dos terreiros, pode-se encontrar hoje também diversos sacerdotes do candomblé que se entendem, de alguma maneira, como parte da "militância negra".

Paralelamente aos debates que ocorriam no Nordeste, um pequeno grupo de lideranças religiosas do Sudeste começava a reivindicar não somente a "dessincretização" do candomblé, mas se preocupava também e sobretudo com a perda de conhecimentos iniciáticos. Para compensar esse déficit, algumas mães e alguns pais de santo - entre eles, aliás, não poucos de cor de pele mais clara - dedicam-se à leitura de estudos etnográficos (sobre a cultura iorubana), assistem a cursos de língua ioruba e/ou fazem viagens para a África, para lugares sagrados na Nigéria e no Benin, de onde trazem, às vezes, objetos sagrados, ou até um título honorífico religioso. Uma tal "experiência africana" poderia servir-lhes como uma estratégia para aumentar o prestígio religioso pessoal e, de certa maneira, permitiu-lhes "burlar" a autoridade das casas baianas que, devido à sua longa história e tradição, gozam de excepcional respeito (axé).

As tentativas de restaurar um campo religioso "puramente africano" (iorubano), i.é., de purificar as práticas religiosas de influências tidas como não-africanas, têm provocado, num “ainda” pequeno número de terreiros

terreiros das articuladoras do manifesto não sofreram alterações relevantes: isto é, não houve "reforma". E mesmo Mãe Stella teve de se confrontar com certa resistência dentro de casa, sobretudo da parte dos mais velhos que não queriam, por exemplo, abrir mão da tradicional missa que acompanhava habitualmente o "axexê".

${ }^{62}$ A posição dos movimentos negros em relação às religiões de matriz africana nem sempre foi assim. Ainda na década de 1930, os líderes da Frente Negra Brasileira, que se viam como devotos católicos, apelavam aos seus filiados que se afastassem das "macumbas", uma vez que viam nelas antros do atraso e de perdição. Posteriormente, ocorreu toda uma reavaliação de tais práticas religiosas e culturais. 0 quilombo e o candomblé tornar-se-iam os exemplos mais importantes da "resistência cultural negra"e, dessa forma, símbolos máximos da "identidade negra". Se a militância pós-abertura democrática, para fundamentar a sua visão de resistência cultural", apoiou-se em noções de cultura desenvolvidas pela antropologia clássica, que frisava a delimitação para fora e, ao mesmo tempo, a homogeneidade para dentro, os frentenegrinos, que nem concebiam a ideia de uma "cultura negra" específica, tinham como objetivo a conquista dos valores da cultura" (no singular), pensada no estilo evolucionista, como sinônimo de civilização e progresso (para um aprofundamento desta questão, cf. HOFBAUER, 2006, p. 341-406). 
que se entendem como "(re)africanizados" (ou "tradicionais renovados" ou, ainda, seguidores da "tradição de òrìxà"), alterações ("reformas") na prática ritualística ${ }^{63}$ que são vistas com certa suspeição pela maioria dos líderes dos candomblés baianos. Vários pais e mães de santo da Bahia (sacerdotes das "diásporas primárias") atribuem tais esforços em modificar a "tradição" à falta de "fundamento religioso". Assim, mãe Stella, p. ex., critica como fanatismo ou modismo as tentativas de resgatar a "essência" do candomblé em terras africanas. Embora não negue a validade de se aprender com os africanos ela mesma já esteve na Nigéria e no Benin -, é enfática em defender a ideia de que "nossas raízes estão aqui" (apud SILVA, 1995, p. 278).

Percebe-se, portanto, que, no contexto da luta pelo reconhecimento do candomblé como religião (por legitimação social e autonomia religiosa) e da disputa por prestígio pessoal dentro do mundo do candomblé, uma minoria intelectualizada de líderes começou a desenvolver duas estratégias discursivas visando, de acordo com os seus propagandistas, a dois diferentes objetivos (reformas) que, dependendo de cada uma das situações locais, podem ou não vir a se complementar: (1) a des-catolização; (2) a (re-)africanização ${ }^{64}$.

A maioria dos sacerdotes do candomblé, que têm como foco de sua atuação sociorreligiosa a vivência no plano local (bairro de uma cidade), demonstra, porém, pouco interesse por inovações ou reformas. Em boa parte das casas predomina, portanto, uma prática ritualística que não se preocupa muito com reconstruções inspiradas, frequentemente, em modelos acadê-

${ }^{63}$ Assim, certas casas promovem, p. ex.,"toques de despedida", em que os caboclos, até então cultuados, são "expulsos", uma vez que passaram a ser entendidos como espíritos ancestrais indígenas que nada têm a ver com a "verdadeira tradição africana" (PRANDI e SILVA, 1989, p. 238). Em outros terreiros, as vestimentas "tradicionais" do candomblé são trocadas por roupas tidas como "mais africanas", as letras das cantigas dos orixás são "corrigidas" etc.

${ }^{64}$ O antropólogo argentino Alejandro Frigerio desenvolveu uma espécie de tipologia dessas estratégias que, de acordo com ele, se aplica a toda diáspora negra americana. Diferentemente de outros pesquisadores, Frigerio diferencia não somente entre primeira diáspora religiosa (local onde as religiões de matriz africana teriam surgido em decorrência do tráfico negreiro - p. ex., Salvador, Havana) e segunda diáspora religiosa (aqueles lugares nos quais a difusão religiosa ocorreu por meio de migrações intra e intercontinentais - p. ex., São Paulo, Buenos Aires, Nova lorque), mas também entre africanização e reafricanização. De acordo com esse pesquisador, muitos adeptos passam ao longo de suas vidas por processos de "conversões sucessivas", que ele relaciona com aprendizagens cumulativas e com transformações identitárias. A africanização seria a primeira fase de transição, que aproxima uma pessoa, que frequenta uma religião com "características sincréticas" (p. ex.: a umbanda, no Brasil; o espiritismo, em Cuba), de uma "prática mais africana" (o candomblé, no Brasil; a santería, em Cuba). A reafricanização ocorreria, segundo Frigerio, quando um seguidor do candomblé (santería) começa a se sentir insatisfeito com os conhecimentos religiosos obtidos por tradição oral, voltando-se para a África com o objetivo de fortalecer (ou reformar) os fundamentos teológicos e ritualísticos de sua religião (FRIGERIO, 2005, p. 141). 
micos, buscando aplicar, de forma contextual e, de preferência, eficaz, as sabedorias cosmológicas que foram e são passadas pelos mais velhos. Dessa forma, os líderes dessas casas resistem também, conscientemente ou não, a projetos de homogeneização das práticas ritualísticas e de centralização do poder religioso num plano supraterreiro.

No entanto, algumas poucas lideranças envolvem-se em processos de (re)africanização, participam de congressos nacionais e internacionais e também começam a participar - via internet - da criação de organizações supralocais e até de comunidades transnacionais incipientes. Engajam-se na elaboração de um discurso que busca apresentar as diversas e, por vezes, divergentes práticas locais e individuais que existem na África e na AfroAmérica como uma religião uniforme, denominando-a de "a religião dos orixás". Referência fundamental no desenvolvimento de uma perspectiva transnacional têm sido os Congressos Mundiais de Tradição e Cultura dos Orixás (World Orisa Congress), que ocorrem, com certa regularidade, desde 1981. Essa organização busca - sob a liderança de intelectuais e sacerdotes iorubanos nigerianos, para os quais a realização dos congressos constitui também uma oportunidade de divulgar as suas visões sobre a "tradição" e de aumentar sua influência para além da Nigéria - criar um fundamento teológico sólido, em torno da rica tradição oracular de Ifá, que permita estabelecer a "religião dos orixás" como uma das "grandes religiões mundiais" (CAPONE, 1999; PALMIÉ, 2005).

Embora os sacerdotes que promovem uma "política radical" de dessincretização e reafricanização sejam uma pequena minoria dentro do espectro das religiões de matriz africana no Brasil, são eles que contribuem de forma fundamental para conferir ao candomblé uma maior "visibilidade" na sociedade brasileira ${ }^{65}$. Seus contatos com a imprensa e com as universidades possibilitam levar as suas ideias sobre o candomblé e a luta contra a intolerância religiosa para além dos muros dos terreiros. É, porém, difícil

\footnotetext{
${ }^{65}$ Prandi tem argumentado que o processo de (re)africanização implica sempre um processo de intelectualização (PRANDI, 1991, p. 118). Chama a atenção o fato de que, no Censo de 2000, o candomblé aparece como a religião cujos adeptos têm o segundo maior nível escolar. Esse resultado aponta para uma participação expressiva de pessoas com diplomas universitários, já que é sabido que a maioria dos adeptos continua a ser de camadas sociais baixas. Segundo Lépine, o processo de (re)africanização em São Paulo foi iniciado sobretudo por uma elite de sacerdotes brancos. Entre eles, há um ou outro que combina a sua atividade de líder religioso com aquela de pesquisador do candomblé. De acordo com Lépine, a (re)africanização do candomblé de São Paulo envolve não mais do que uma dúzia de terreiros (LÉPINE, 2005, p. 128-133).
} 
avaliar até que ponto o seu discurso sobre "a tradição" e sobre a relação entre o candomblé e a sociedade ao redor encontrará repercussão no meio das comunidades religiosas. Estudos mais recentes têm mostrado que é possível encontrarmos, por vezes, visões bastante divergentes a respeito de importantes aspectos da crença e das práticas religiosas dentro de um único terreiro. Assim, ocorre que iniciados em casas que se dizem (re)africanizadas não deixam de ser devotos de um determinado santo, já outros continuam tendo apreço pelos caboclos. Nem todos rompem com a Igreja Católica e, não raramente, atribuem características tipicamente cristãs às divindades iorubanas e comparam-nas com os santos católicos (MELO, 2004, p. 147165). Se o orixá é visto e vivenciado como uma "divindade africana pura" ou se ele é associado, de alguma forma, também a um santo católico, depende, portanto, não somente dos ensinamentos e da postura do líder religioso que iniciou o adepto, mas também, em boa medida, das experiências particulares de vida de cada pessoa e, especialmente, das experiências pessoais com os outros mundos religiosos (conversion careers, cf. RICHARDSON, 1980).

Como ocorre com qualquer outro fenômeno social, a categoria "candomblé" sempre foi disputada - afirmada, acomodada, desafiada e contestada - por diferentes discursos e práticas. Vimos que não foram somente os diálogos transatlânticos mencionados por Matory, mas também as disputas intraterreiros por prestígio religioso e a luta por reconhecimento dentro da sociedade brasileira que impulsionaram inovações religiosas e levaram a novas interpretações da "tradição". Assim, práticas de assimilação de outras divindades e de incorporação de elementos culturais "estranhos" com o objetivo de apropriar-se deles e, por seu intermédio, exercer poder, registradas como tendências comuns entre várias "tradições" africanas (inclusive entre os iorubas e os fon), começaram a ser vistas por certas elites do candomblé como sinal de decadência cultural e religiosa.

Faz algum tempo que um pequeno grupo de lideranças religiosas transnacionais recorre a "tecnologias" e formas organizatórias comumente associadas ao mundo ocidental - p. ex., a codificação do saber teológico e a realização de congressos - com o objetivo de conferir às variadas práticas da "religião dos orixás" uma estrutura organizacional unificadora e uma base doutrinária uniforme capaz de facilitar, inclusive, o combate à discriminação e a conquista do respeito às crenças e práticas ritualísticas enquanto uma religião entre outras. Elaborando análises e discursos que não carecem de 
acribia acadêmica, os protagonistas desse projeto procuram separar o joio do trigo para, por meio da restauração da suposta "essência originária" da "religião dos orixás", iniciar a construção de uma grande religião mundial.

O que os adeptos, os cientistas e as "pessoas comuns" entendem como "mistura" ou "cultura" ("religião") autêntica e qual a importância que atribuem ao "hibridismo" ou à "africanidade" sempre foi e continua sendo objeto de discussões e debates ${ }^{66}$. Tais divergências refletem-se, evidentemente, também nas diferentes interpretações sobre quais atitudes e práticas devem ser lidas como "formas de resistência" ${ }^{67}$ e quais como "sinais de assimilação". Controvérsias como a travada entre Sweet e Thornton, mas também aquela entre Matory e Dantas, remontam não somente à aplicação de diferentes noções de cultura - mais ou menos essencializantes, dinâmicas e/ou "pós-modernas". Por trás de tais discussões escondem-se também atitudes divergentes diante da produção de conhecimento, assim como diferentes posicionamentos perante os respectivos "objetos/sujeitos de pesquisa". Tais atitudes e posicionamentos expressam, acima de tudo, a disputa em torno do discurso acadêmico hegemônico, que se articula concomitantemente numa relação dialógica, porém nem sempre livre de conflitos, com os acontecimentos que ocorrem dentro dos templos diaspóricos e africanos.

Vimos que todo discurso que procura definir atitudes e ações humanas baseando-se no "critério" de "pureza (autenticidade) cultural" constitui um posicionamento sociopolítico, e tende ainda a omitir ambiguidades e/ou "hibridações" (no sentido de Bhabha) que qualquer ato e ideia pode provocar. Se quisermos compreender a complexidade e multidimensionalidade dos processos socioculturais sem abrirmos mão dos valores éticos que orientam, em última instância, o nosso posicionamento neste debate sobre dominação, assimilação e contrapoder, parece-me intelectualmente mais profícuo e moralmente mais defensável não partirmos de noções preestabelecidas e

${ }^{66}$ O debate antropológico sobre o sincretismo tem demonstrado tal complexidade (FERRETTI, 1995). Van der Veer tem argumentado que o termo do sincretismo só terá utilidade se deixarmos de usá-lo como um conceito descritivo e passarmos a concebê-lo como parte do discurso religioso, empregando-o para analisar o plano das disputas em torno da legitimidade religiosa. Como, de acordo com esse estudioso, a questão do sincretismo está relacionada, em última instância, com “a política da diferença e da identidade" e, portanto, com o poder de incluir e excluir, as análises antropológicas deveriam concentrar-se na avaliação daqueles discursos que procuram controlar a identificação de algumas práticas religiosas como verdadeiras e outras como falsas (VAN DER VEER, 1994, p. 196, 208).

${ }^{67}$ Cf. tb. as reflexões críticas de Hollander e Einwohner (2004) sobre as diferentes compreensões e os diversos usos do conceito resistência em estudos sociológicos e antropológicos da atualidade. 
descontextualizadas a respeito do certo e do errado, daquilo que liberta e daquilo que é imitação das práticas hegemônicas. Um dos objetivos deste pequeno ensaio foi mostrar que é mais proveitoso analisarmos como, por meio da articulação de signos e significados, indivíduos e grupos tecem relações de poder ao mesmo tempo em que promovem processos de identificação e de delimitação; como a articulação de signos e significados "parte de", ou seja, tem como referência determinadas perspectivas cognitivas e valorativas, e como por meio dela a própria configuração (semântica e estrutural) do campo da cultura - que é ao mesmo tempo campo do poder - é (re) afirmada ou alterada.

O estudo de caso aqui abordado procurou, portanto, ilustrar como os agentes sociais são envolvidos em processos de construção e de desconstrução, ou seja, como construção e desconstrução se articulam e "se cruzam" nas interações socioculturais. Diversos estudos antropológicos e pós-coloniais recentes têm chamado a atenção para o fato de que qualquer intervenção social está sujeita a diferentes leituras por parte de outros agentes sociais que participam ativamente de um mesmo campo - onde se travam as disputas pela definição do significado das "coisas" e das posições dos "sujeitos". É, em última instância, por meio de um constante jogo de posicionamentos dos sujeitos que, nos diversos espaços e contextos sociais, significados e identidades são afirmados e contestados, construídos e desconstruídos.

\section{Referências bibliográficas}

ABU-LUGHOD, Lila. 1991. "Writing against culture". In: FOX, Richard (org.). Recapturing anthropology: working in the present. Santa Fe, New Mexico: School of American Research Press.

BARTH, Fredrik. 1969. “Introduction”. In: BARTH, Fredrik (org.). Ethnic groups and boundaries: the social organization of cultural difference. Oslo/London: Universitets Forlaget/ George Allan and Unwin. BASTIDE, Roger. 1983. Estudos afro-brasileiros. São Paulo: Perspectiva. . 1985. As religiões africanas no Brasil. São Paulo: Livraria Pioneira. BERGER, Peter. 2008. "Secularization falsified". First Things, n. 180, p. 1-7. BHABHA, Homi K. 2001 [1994]. O local da cultura. Belo Horizonte: Ed. UFMG.

BOURDIEU, Pierre. 1972. Esquisse d'une théorie de la pratique, précédé de trois études d'ethnologie kabyle. Genebra: Librairie Droz. 
CAMPOS, Vera Felicidade de Almeida. 2003. Mãe Stella de Oxóssi: perfil de uma liderança religiosa. Rio de Janeiro: Zahar.

CAPONE, Stefania. 1999. "Uma religião para o futuro: a rede transnacional dos cultos afro-americanos". Trabalho apresentado na IX Jornada sobre Alternativas Religiosas na América Latina. Rio de Janeiro, 21-24 de setembro.

.2008. "Transatlantic dialogue: Roger Bastide and the African American religions”. In: PALMIÉ, Stephane (org.). Africas of the Americas: beyond the search for origins in the study of Afro-Atlantic religions. Leiden: Brill.

CHAKRABARTY, Dipesh. 2000. Provincialising Europe: postcolonial thought and historical difference. Princeton: Princeton University Press.

CONSORTE, Josildeth Gomes. 1999. "Em torno de um manifesto de ialorixás baianas contra o sincretismo”. In: CAROSO, Carlos \& BACELAR, Jeferson (orgs.), Faces da tradição afro-brasileira. Rio de Janeiro: Pallas. COSTA, Sérgio. 2005. “(Un)möglichkeiten einer postkolonialen Soziologie”. In: BRUNKHORST, Hauke \& COSTA, Sérgio (orgs.). Jenseits von Zentrum und Peripherie: zur Verfassung der fragmentierten Weltgesellschaft. München: Rainer Hampp Verlag.

.2006. Dois Atlânticos: teoria social, anti-racismo, cosmopolitismo. Belo Horizonte: Ed. UFMG.

DANTAS, Beatriz Góis. 1988. Vovó nagô e papai branco. Rio de Janeiro: Graal. ERIKSEN, Thomas Hylland. 2001. "Ethnic identity, national identity and intergroup conflict: the significance of personal experiences". In: ASHMORE, Richard D.; JUSSIM, Lee J. \& WILDER, David (orgs.). Social identity, intergroup conflict, and conflict reduction. Oxford: Oxford University Press.

FERRETTI, Sérgio Figueiredo. 1995. Repensando o sincretismo. São Paulo: EDUSP.

FRIGERIO, Alejandro. 2005. "Reafricanização em diásporas religiosas secundárias: a construção de uma religião mundial”. Religião e Sociedade, v. 25 , n. 2, p. 136-160.

GEERTZ, Clifford. 1973. “Thick description: toward an interpretive theory of culture”. In: GEERTZ, Clifford. The interpretation of cultures: selected essays. New York: Basic Books.

GILROY, Paul. 2000. Against race: imagining political culture beyond the 
color line. Cambridge/Massachusetts: Harvard University Press.

HALL, Stuart. 1991. "Old and new identities, old and new ethnicities". In: KING, Anthony D. (org.). Culture, globalization, and the world-system. New York: MacMillan.

1996a. "When was 'the postcolonial"? thinking at the limit". In: CHAMBERS, Iain \& CURTIS, Lidia (orgs.). The postcolonial question: common skies, divided horizons. London: Routledge.

. 1996b. "The West and the rest: discourse and power". In: HALL,

Stuart et al. (orgs.). Modernity: introduction to the modern societies. Oxford: Blackwell. . 2000. "A produção social da identidade e da diferença". In: SILVA, Tomaz Tadeu da (org.). Identidade e diferença: a perspectiva dos estudos culturais. Petrópolis, RJ: Vozes.

.2001. A identidade cultural na pós-modernidade. Rio de Janeiro: DP\&A. . 2003. "Que 'negro' é esse na cultura negra?". In: HALL, Stuart. Da diáspora. Identidades e mediações culturais. Organização de Liv Sovik. Belo Horizonte: Ed. UFMG.

HARDING, Rachel E. 2000. A refuge in thunder: candomblé and alternative spaces of blackness. Bloomington/Indianapolis: Indiana University Press. HEIN, Kerstin. 2006. Hybride Identitäten: Bastelbiografien im Spannungsverhältnis zwischen Lateinamerika und Europa. Bielefeld: Transcript.

HEYWOOD, Linda M. 2002. "Portuguese into African: the eighteenthcentury central African background to Atlantic creole culture". In: HEYWOOD, Linda M. (org.). Central Africans and cultural transformations in the American diaspora. Cambridge: Cambridge University Press. HOFBAUER, Andreas. 2006. Uma história de branqueamento ou o negro em questão. São Paulo: UNESP.

. 2009. "Entre olhares antropológicos e perspectivas dos estudos culturais e pós-coloniais: consensos e dissensos no trato das diferenças". Antropolítica, n. 27, p. 99-130.

HOLLANDER, Jocelyn A. \& EINWOHNER, Rachel L. 2004. "Conceptualizing resistance". Sociological Forum, v. 19, n. 4, p. 533-554.

KIMMERLE, Heinz. 2000. Jacques Derrida zur Einführung. Hamburg: Junius. LÉPINE, Claude. 2005. "Mudanças no candomblé". Religião e Sociedade, v. 25, n. 2, p. 121-135.

LOOMBA, Ania. 2005. Colonialism / postcolonialism. London: Routledge. 
MALEŠEVIĆ, Siniša. 2004. The sociology of ethnicity. London: Sage.

MARCHART, Oliver. 2008. Cultural studies. Stuttgart: UVK.

MACGAFFEY, Wyatt. 1994. "African objects and the idea of fetish". Anthropology and Aesthetics, n. 25, p.123-131.

MATORY, J. Lorand. 1998. "Yorubá: as rotas e as raízes da nação transatlântica, 1830-1950". Horizontes Antropológicos, v. 4, n. 9, p. 263-292. . 1999. “Jeje: repensando nações e transnacionalismo”. Mana, v. 5, n. 1, p. $57-80$.

2005. Black Atlantic religion: tradition, transnationalism, and matriarchy in the Afro-Brazilian candomblé. Princeton: Princeton University Press.

MELO, Aislan Vieira de. 2004. A voz dos fiéis no candomblé "reafricanizado" de São Paulo. Dissertação de mestrado. Marília: UNESP.

MOURA, Clóvis. 1983. Brasil: as raízes do protesto negro. São Paulo: Global. MULVEY, Patricia. 1982. "Slave confraternities in Brazil: their role in colonial society". The Americas, v. 39, n. 1, p. 39-68.

. 1999. "Festas and funerals: funerary politics and the afro-christian brotherhoods of colonial Brazil". Plantation Society in the Americas, v. 6, n. 2\&3, p. 257-271.

MÜLLER-FUNK, Wolfgang. 2006. Kulturtheorie. Tübingen: UTB.

ORTNER, Sherry. 2006. Anthropology and social theory: culture, power, and the acting subject. London: Duke University Press.

PALMIÉ, Stephan. 1995. "Against syncretism: 'Africanizing' and 'Cubanizing' discourses in North American òrìsà worship”. In: FARDON, Richard (org.). Counterworks: managing the diversity of knowledge. London: Routledge.

. 2005. "The cultural work of Yoruba globalization". In: FALOLA, Toyin (org.). Christianity and social change in Africa. Durham: Carolina Academic Press.

(org.). 2008. Africas of the Americas: beyond the search for origins in the study of Afro-Atlantic religions. Leiden: Brill.

PARÉS, Luis Nicolau. 2006. A formação do candomblé. Campinas: Ed. Unicamp. PIETERSE, Jan Nederveen. 2010. “New modernities: what's new?". In: RODRÍGUEZ, Encarnación Gutiérrez; BOATCĂ, Manuela \& COSTA, Sérgio (orgs.). Decolonizing European sociology: transdisciplinary approaches. Farnham: Ashgate. 
PEREIRA, João Baptista Borges. 1984. "A cultura negra: resistência de cultura à cultura de resistência”. Dédalo. Revista do Museu de Arqueologia e Etnologia, n. 23, p. 177-188.

POUTIGNAT, Philippe \& STREIFF-FENART, Jocelyne. 1997. Teorias da etnicidade. São Paulo: UNESP.

PRANDI, Reginaldo. 1991. Os candomblés de São Paulo. São Paulo: Hucitec. . 1996a. Herdeiras do axé. São Paulo: Hucitec. . 1996b. "Religião paga, conversão e serviço". Novos Estudos, n. 45, p. 65-77.

. 2000. "Hipertrofia ritual das religiões afro-brasileiras". Novos Estudos, n. 56, p. 77-88.

2003. "As religiões afro-brasileiras e seus seguidores". Civitas, v. 3, n. 1, p. 15-33.

\& SILVA, Vagner G. 1989. “Axé São Paulo”. In: MOURA, Marcondes (org.). Meu sinal está no teu corpo: escritos sobre a religião dos orixás. São Paulo: Edicon/ EDUSP.

RAMOS, Arthur. 1979. As culturas negras no novo mundo. São Paulo: Ed. Nacional.

RANDERIA, Shalini. 1999. "Geteilte Geschichte und verwobene moderne". In: RÜSEN, Jörn et al. (orgs.). Zukunftsentwürfe: Ideen für eine Kultur der Veränderung. Frankfurt am Main: Campus.

REIS, João José. 1996. "Identidade e diversidade étnicas nas irmandades negras no tempo da escravidão". Tempo, v. 2, n. 3, p. 7-33.

REUTER, Julia \& VILLA Paula-Irene. 2010. "Provincializing Soziologie: postkoloniale Theorie als Herausforderung“. In: REUTER, Julia e VILLA Paula-Irene (orgs.). Postkoloniale Soziologie. Empirische Befunde, theoretische Anschlüsse, politische Intervention. Bielefeld: Transcript.

RICHARDSON, James. 1980. “Conversion careers”. Society, n. 17, p. 47-50. RODRIGUES, Raimundo Nina. 1977. Os africanos no Brasil. São Paulo: Ed. Nacional.

SAHLINS, Marshall. 1981. Historical metaphors and mythical realities: structure in the early history of the Sandwich Islands Kingdom. Ann Arbor: University of Michigan Press.

. 1997. "O 'pessimismo sentimental' e a experiência etnográfica: por que a cultura não é um 'objeto' em via de extinção (parte I)”. Mana, v. 3 , n. 1, p. 41-73. 
2002 [1993]. Waiting for Foucault, still. Chicago: Prickly Paradigm. SCARANO, Julita. 1978. Devoção e escravidão. São Paulo: Ed. Nacional. SERRA, Ordep. 1995. Águas do rei. Petrópolis, RJ: Vozes.

SILVA, Luiz Geraldo. 2005. "Da festa barroca à intolerância ilustrada. Irmandades católicas e religiosidade negra na América portuguesa (17501815)". In: SALLES-REESE, Verónica (org.). Repensando el pasado, recuperando el futuro: nuevos aportes interdisciplinarios para el estúdio de la América colonial. Bogotá: Editorial Pontificia Universidad Javeriana. SILVA, Luiz Geraldo. s/d. "Governos e reinados negros: conflito, hierarquia e poder entre crioulos e africanos (Pernambuco, 1750-1814)”. Disponível em: http://sitemason.vanderbilt.edu/files/dZPG8g/Silva\%20Luiz\%20 Geraldo.doc

SILVA, Vagner Gonçalves da. 1995. Orixás na metrópole. Petrópolis, RJ: Vozes. SILVEIRA, Renato da. 2006. "Sobre o exclusivismo e outros ismos das irmandades negras na Bahia colonial”. In: BELLINI, Lígia, SOUZA; SALES, Evergton \& SAMPAIO, Gabriela dos Reis (orgs.). Formas de crer: ensaios de história religiosa do mundo luso-afro-brasileiro, séculos XIV-XXI. Salvador: Ed. UFBA.

SIQUEIRA, Maria de Lourdes. 1989. “A força que anima”. Jornal Nacional do Movimento Negro, n. 16, p. 8-9.

SOUZA, Marina de Mello e. 2002a. "Catolicismo negro no Brasil: Santos e minkisi, uma reflexão sobre miscigenação cultural”. Afro-Ásia, n. 28, p. 125-146.

.2002b. Reis negros no Brasil escravista: história da festa de coroação de rei Congo. Belo Horizonte: Ed. UFMG.

SWEET, James. H. 2003. Recreating Africa: culture, kinship, and religion in the African-Portuguese world, 1441-1770. Chapel Hill: The University of North Carolina Press.

THORNTON, John K. 1981. "Early Kongo-Portuguese relations: a new interpretation". History in Africa, n. 8, p. 183-204.

. 2002. "Religious and ceremonial life in the Kongo and Mbunda areas, 1500-1700". In: HEYWOOD, Linda M. (org.). Central Africans and cultural transformations in the American diaspora. Cambridge: Cambridge University Press.

VAN DER VEER, Peter. 1994. "Syncretism, multiculturalism and the discourse of tolerance”. In: STEWART, Charles \& SHAW, Rosalind (orgs.). 
Syncretism/anti-syncretism: the politics of religious synthesis. London: Routledge.

VARELA, María do Mar Castro \& DHAWAN, Nikita. 2005. Postkoloniale Theorie. Bielefeld: Transcript.

\section{Resumo}

Este ensaio debate a questão da dominação e do contrapoder com base no exemplo de alguns momentos específicos da história do candomblé. Partindo de uma reflexão sobre perspectivas teóricas antropológicas e pós-coloniais recentes sobre cultura, identidade e poder, procura-se mostrar que o candomblé se apresenta como um campo disputado, não apenas internamente, mas, inclusive, no que diz respeito à sua delimitação externa. Argumenta-se que uma aproximação entre olhares antropológicos e preocupações pós-coloniais pode ajudar a entender melhor como os agentes sociais tecem, por meio da articulação de signos e significados, relações de poder ao mesmo tempo em que promovem atos de identificação e de delimitação; e, como este processo contribui para a construção e desconstrução dos cenários de dominação e de contrapoder.

Palavras-chave: resistência negra; candomblé; identidade; diferença; teorias antropológicas; pós-colonial.

\section{Abstract}

This article discusses the topic of domination and counter-power using the example of some specific moments of the history of the Candomble. Based on reflections about recent theoretical anthropological and postcolonial perspectives on culture, identity and power, the author tries to show that the Candomble is a disputed terrain not only internally, but also with reference to its outer boundaries. As anthropological perceptions get closer to postcolonial concerns it helps us to get a better understanding of how social agents weave power relations through the articulation of signs and signifiers while promoting acts of identification and delimitation; and how this process contributes to the construction and deconstruction of the scenarios of domination and counter-power.

Keywords: Black resistance; Candomble; identity; difference; anthropological; postcolonial theories.

Recebido em outubro de 2010.

Aprovado em dezembro de 2010. 
